La construcción de un pensamiento crítico acerca de los roles de género a través de la literatura infantil. ....

\title{
LA CONSTRUCCIÓN DE UN PENSAMIENTO CRÍTICO ACERCA DE LOS ROLES DE GÉNERO A TRAVÉS DE LA LITERATURA INFANTIL. ANÁLISIS DE UN PROCESO DE INVESTIGACIÓN-ACCIÓN CON NIÑOS Y NIÑAS DE 5 AÑ̃S
}

Marta SANJUÁN ÁLVAREZ

Universidad de Zaragoza

msanjalv@unizar.es

María BALLARÍN ARTIGAS

mariaballarinartigas@gmail.com

Resumen: Este trabajo describe un diseño de intervención e investigación en un aula de 3. ${ }^{\circ}$ de Educación Infantil, dirigido a estimular el pensamiento crítico en torno a los roles de género. El diseño incluye un cuestionario previo para conocer las creencias iniciales de los participantes y varias sesiones de lectura y conversación literaria. Las obras seleccionadas representan distintas posiciones ideológicas y tratamientos literarios de los personajes masculinos y femeninos, y abarcan un lapso temporal muy amplio, con la finalidad de promover la comparación y la reflexión desde una perspectiva social evolutiva. Los resultados muestran que los niños y niñas de Educación Infantil ya tienen unas ideas de género estereotipadas. Sin embargo, la discusión y el análisis guiado de las obras literarias les han llevado a cuestionar sus estereotipos, lo que confirma el valor de la literatura infantil en la construcción de la identidad individual y social, la percepción crítica de la realidad y el desarrollo de esquemas éticos reflexivos desde la primera infancia, siempre que se estimule una recepción lectora crítica. 
Marta Sanjuán Álvarez y María Ballarín Artigas

Palabras clave: literatura infantil y roles de género, literatura y construcción de la identidad, respuestas lectoras, conversación literaria, literatura en Educación Infantil

\section{LA CONSTRUCTION D'UNE RÉFLEXION CRITIQUE SUR LES RÔLES DE GENRE À TRAVERS LA LITTÉRATURE POUR ENFANTS. ANALYSE D'UN PROCESSUS DE RECHERCHE-ACTION AVEC DES ENFANTS DE 5 ANS}

Résumé: Cet article décrit un plan d'intervention et de recherche dans une 3ème classe d'éducation préscolaire, visant à stimuler la réflexion critique sur les rôles de genre. Le plan comprend un questionnaire préliminaire pour connaître les idées initiales des participants, ainsi que plusieurs séances de lecture et conversation littéraire. Les œuvres sélectionnées représentent différentes positions idéologiques et traitements littéraires des personnages masculins et féminins, et couvrent une très longue période, afin de favoriser la comparaison et la réflexion dans une perspective sociale évolutive. Les résultats montrent que les enfants en âge préscolaire ont déjà des idées stéréotypées sur le genre. Cependant, la discussion et l'analyse guidée d'œuvres littéraires les ont amenés à mettre en doute leurs stéréotypes, ce qui confirme la valeur de la littérature pour enfants dans la construction de l'identité individuelle et sociale, la perception critique de la réalité et le développement de schémas éthiques réflexifs dès la petite enfance, à condition que la lecture critique soit stimulée.

Mots clés: littérature pour enfants et rôles de genre, littérature et construction de l'identité, réponses à la lecture, conversation littéraire, littérature en éducation de la petite enfance.

\section{THE CONSTRUCTION OF A CRITICAL THINKING ABOUT GENDER ROLES THROUGH CHILDREN'S LITERATURE. ANALYSIS OF AN ACTION RESEARCH PROCESS WITH CHILDREN OF 5 YEARS}

Abstract: This paper describes an intervention and research design in a third grade classroom 
La construcción de un pensamiento crítico acerca de los roles de género a través de la literatura infantil. ....

for Early Childhood Education, aimed at stimulating critical thinking about gender roles. The design includes a previous questionnaire to know the original beliefs of the participants, and several sessions of reading and literary conversation. The selected works represent different ideological positions and literary treatments of male and female characters, and cover a very long lapse of time, in order to promote comparison and critical thought from a social perspective over time. The results show that the boys and girls of Early Childhood Education already have stereotyped gender ideas. However, the discussion and guided analysis of literary works have led them to question their stereotypes. This confirms the value of children's literature in the construction of individual and social identity, the critical perception of reality and the development of reflexive ethical schemes from early childhood, whenever a critical reading reception is stimulated.

Key words: children's literature and gender roles, literature and construction of identity, reading responses, literary conversation, literature in Early Childhood Education

\section{Introducción. Planteamiento del problema y justificación de la investigación}

Desde los años 70 del siglo pasado son numerosas las investigaciones sobre lengua, literatura y género (véase la revisión realizada por Molina, 2007). Como un campo especializado dentro de este interés por los estudios de género, son también abundantes los trabajos sobre la presencia de estereotipos masculinos y femeninos en la literatura infantil y juvenil (LIJ). No obstante, estos estudios se centran casi en exclusiva en el análisis de los textos y las ilustraciones, no así en las respuestas lectoras que estas obras producen en los lectores infantiles y juveniles.

Con nuestro estudio pretendemos, por el contrario, reflexionar sobre la importancia de la LIJ en la construcción de la identidad de niños y niñas, y analizar si la lectura crítica de los receptores infantiles acerca de la caracterización de los personajes masculinos y femeninos puede facilitar el desarrollo de unos planteamientos más igualitarios. El trabajo se enfoca como un proceso de investigación-acción centrado en la potencialidad de la LI para crear experiencias cognitivas, emocionales y socioculturales transformadoras de la visión del género que la sociedad impone desde edades tempranas a través de ciertos medios de transmisión cultural. El objetivo fundamental de la investigación-acción consiste en mejorar la práctica educativa (Elliot, 1993, p. 67). En este sentido, nuestro proceso investigador ha 


\section{Marta Sanjuán Álvarez y María Ballarín Artigas}

partido de un análisis inicial de las creencias de un grupo de niños y niñas de Educación Infantil en torno a los roles de género, cuyos resultados han dado lugar al diseño, desarrollo y evaluación de una intervención docente en el aula de referencia de los informantes. La finalidad de nuestro estudio se dirige a evaluar si la literatura infantil ha contribuido a modificar los esquemas éticos y socioculturales iniciales.

La intervención se ha desarrollado en un colegio de Zaragoza a lo largo de cuatro meses, con 10 niñas y 10 niños de $3 .^{\circ}$ de Educación Infantil, 15 de ellos de 5 años y otros 5 de 6 . Sus características son muy diversas en cuanto a procedencias (Europa, Latinoamérica, norte de África), entornos familiares, religiosos, culturales y socioeconómicos, así como niveles cognitivo-lingüísticos. Una de las autoras de este trabajo ha actuado en el doble papel de investigadora y docente.

La investigación parte de dos presupuestos iniciales, que dan lugar a unos objetivos y preguntas de investigación, tal como se muestra en la Tabla 1:

Tabla 1. Presupuestos de partida, objetivos y preguntas de investigación

\begin{tabular}{|l|l|l|}
\hline PRESUPUESTOS DE PARTIDA & \multicolumn{1}{|c|}{$\begin{array}{c}\text { OBJETIVOS DE INVESTI- } \\
\text { GACIÓN }\end{array}$} & $\begin{array}{l}\text { PREGUNTAS DE INVES- } \\
\text { TIGACIÓN }\end{array}$ \\
\hline $\begin{array}{l}\text { 1. Los niños y niñas de Educación } \\
\text { Infantil ya tienen unas ideas } \\
\text { sexistas sobre los roles de género. }\end{array}$ & $\begin{array}{l}\text { 1.1. Descubrir ideas y creencias de } \\
\text { los niños y niñas participantes acerca } \\
\text { de los roles de género en la vida y } \\
\text { en la literatura infantil, previas a la } \\
\text { intervención en el aula. }\end{array}$ & $\begin{array}{l}\text { 1.1.1. ¿Tienen los niños y } \\
\text { niñas de Educación Infantil } \\
\text { unas ideas y creencias ya } \\
\text { establecidas acerca de los } \\
\text { roles de género en la vida y } \\
\text { en la literatura infantil? }\end{array}$ \\
& $\begin{array}{l}\text { 1.1.2.¿Reproducen esas ideas } \\
\text { determinados estereotipos } \\
\text { sexistas claramente } \\
\text { apreciables en el entorno } \\
\text { sociocultural? }\end{array}$ \\
\hline
\end{tabular}


La construcción de un pensamiento crítico acerca de los roles de género a través de la literatura infantil. ....

\begin{tabular}{|c|c|c|}
\hline $\begin{array}{l}\text { 2. La literatura infantil, a través } \\
\text { de la recepción crítica guiada, } \\
\text { puede contribuir a la reflexión y a } \\
\text { la modificación de los esquemas } \\
\text { de pensamiento sobre los roles de } \\
\text { género ya en la Educación Infantil. }\end{array}$ & $\begin{array}{l}\text { 2.1. Establecer unos criterios para } \\
\text { seleccionar un corpus de obras de LI } \\
\text { adecuadas para favorecer el debate } \\
\text { y la reflexión acerca de los roles de } \\
\text { género en la etapa de Educación } \\
\text { Infantil. } \\
\text { 2.2. Valorar si la LI y la conversación } \\
\text { literaria (enfoque Dime de } \\
\text { Chambers, 2007) pueden contribuir } \\
\text { a la modificación de los esquemas } \\
\text { éticos y socioculturales de los } \\
\text { sujetos participantes en torno a los } \\
\text { roles de género. }\end{array}$ & $\begin{array}{l}\text { 2.1.1. ¿Qué tipo de obras de } \\
\text { LI pueden propiciar el debate } \\
\text { y la reflexión acerca de los } \\
\text { roles de género en la etapa } \\
\text { de EI? } \\
2.1 .2 . \text { ¿Conviene incluir obras } \\
\text { representativas de distintas } \\
\text { épocas y planteamientos? } \\
\text { 2.2.1. ¿Puede la LI, a través } \\
\text { de la recepción crítica } \\
\text { guiada, contribuir a la } \\
\text { modificación de las ideas } \\
\text { y creencias previas de los } \\
\text { participantes en torno a los } \\
\text { roles de género? }\end{array}$ \\
\hline
\end{tabular}

El primer presupuesto viene avalado por investigaciones como las de Guil Bozal (1998), Aznar Díaz y Fernández Martín (2004) o Schaffer (2000) (todas ellas cit. por Ros García, 2012/2013, p. 334), según las cuales a los 3-4 años se adoptan los roles de género, entendidos como una construcción social que se concreta en intereses, actividades, ocupaciones y preferencias por juegos tipificados en razón del género. Un estudio realizado por Carreras, Subirats y Tomé (2012) en guarderías municipales de Barcelona con niños y niñas de 0 a 3 años muestra cómo los mecanismos de socialización (lenguaje, cuentos y juguetes, interacción con las educadoras, uso de los espacios) ya están impregnados de estereotipos sexistas.

El segundo presupuesto nace de la convicción de que la literatura puede influir decisivamente en la construcción del imaginario del lector, y por tanto puede dar pie a una reflexión y transformación de las creencias ya existentes en los lectores infantiles. Avalan esta idea las investigaciones de etnografía de la lectura de autores como Peroni (1998), Petit (1999, 2001) o Argüelles (2003, 2005), así como en torno al concepto de experiencia de la lectura, entendida como aquel proceso de la recepción de textos literarios que puede dar lugar a la transformación de los esquemas vitales del lector (Rosenblatt, 1938/1995; Salinas, 1948; Lewis, 1961; Larrosa, 2003; Compagnon, 2007).

\section{Marco teórico}

\subsection{A vueltas con la función formativa de la literatura infantil}

La transmisión de valores sociales y culturales, como los roles de género, se inserta en un debate general sobre cómo la LIJ puede alcanzar una función educativa sin perder su naturaleza literaria. 


\section{Marta Sanjuán Álvarez y María Ballarín Artigas}

Todavía hoy multitud de editoriales ponen la literatura infantil al servicio de la transmisión de contenidos morales. Siguiendo las ideas aportadas desde hace décadas por numerosos estudiosos (Cervera, 1984; Rico, 1986; Sánchez Corral, 1995; Machado, 2000, 2015; Bajour y Carranza, 2005; Carranza, 2006, 2009; Tejerina y Echevarría, 2007; Etxaniz, 2011), defendemos, por el contrario, que una literatura infantil de calidad es incompatible con el didactismo explícito, lo cual no quiere decir que en ella no estén presentes los conflictos morales y sociales (Sanjuán, 2018). Al ser una forma de arte, el texto literario debería dar lugar a diferentes posibilidades de significación y favorecer la libertad interpretativa del lector:

Si la literatura nos habla del mundo y nos transforma, no lo hace transmitiéndonos formas ya digeridas de cómo ver el mundo y cómo actuar en él. No es su función decirnos cómo debemos pensar y actuar según formas canonizadas, instituidas, oficiales de pensamiento y acción (Carranza, 2006).

Para Shavit (1986, cit. por Carranza, 2009), la literatura infantil sufre numerosas formas de censura, desde la idea de infancia de cada periodo histórico y cultural hasta el ajuste de los temas, la trama, los personajes o el lenguaje a aquello que la sociedad considera como apropiado para los niños en cada momento.

Frente a este control moral, se puede concebir la lectura como experiencia ética (Mata, 2009, 2014): una obra literaria no transmite valores, pero puede propiciar emociones y reflexiones que transformen al lector. En determinadas ocasiones la lectura se convierte en una experiencia vital que ayuda a construir la identidad individual, cultural y social de los lectores (Sanjuán, 2007; Sanjuán y Senís, 2017). Lograr experiencias lectoras significativas en contextos educativos no es tarea sencilla: la lectura debe ser un proceso activo guiado por el mediador, a través del cual el lector en formación se haga preguntas y busque en los diferentes textos las respuestas aplicables a su vida diaria. Esta reflexión ética que la literatura puede propiciar en los receptores infantiles se verá favorecida por una selección de obras que aborden temas y situaciones humanas relevantes para ellos, sin necesidad de didactismos y sin renunciar al desarrollo simultáneo de experiencias estéticas gratificantes, indispensables para la formación de lectores literarios.

\subsection{Literatura infantil y roles de género}

Desde hace décadas, investigadores como Cerdá (1978), Cañellas (1979), Turin (1995), Aguilar 


\section{La construcción de un pensamiento crítico acerca de los roles de género a través de la literatura infantil. ....}

(2008), Pastor (2009/2010) o Ros García (2012/2013), entre otros, denuncian los estereotipos sexistas en la LIJ. Para Cervera (1984), estos estereotipos no son un mero reflejo de la sociedad, sino una utilización consciente de la literatura para imponer la hegemonía patriarcal. Turin (1995) afirma que la literatura infantil es «la vieja máquina» de inculcar a los niños los papeles sexuales. Solo un $34 \%$ de los protagonistas infantiles de los libros ilustrados analizados en su investigación son niñas, y en general los personajes femeninos desempeñan papeles estereotipados y a menudo de escasa importancia. Desde el punto de vista cualitativo, «Las imágenes estereotipadas de la mujer y del hombre que trasmiten los libros infantiles son mutilantes para las niñas y empobrecedoras para los niños», afirma Turin (1995, p. 8). Las mujeres son pasivas, sensibles, obedientes, incluso bobas. Se dedican al hogar y los hijos, y su vida se basa en la espera. Los cuentos maravillosos muestran principalmente tres imágenes de la mujer: la princesa bella, la reina madre y la bruja fea y malvada (Cashdan, 2000). En la literatura occidental la imagen de la mujer ha estado ligada a su representación por la Iglesia Católica como incitadora al pecado; su debilidad, argumentan los Padres de la Iglesia, la hace vulnerable a las influencias diabólicas.

Frente a los limitados papeles femeninos encontramos una gran variedad de papeles masculinos; tienen oficios y aventuras fuera del espacio doméstico, aunque también existen estereotipos masculinos, como el de príncipe salvador.

Un tema habitual en los cuentos, directamente relacionado con los roles de género, es el del amor y el matrimonio. La libertad individual se ve especialmente mermada en la mujer, que es tratada como objeto de intercambio. El padre tiene que estar de acuerdo con el matrimonio para que este sea efectivo, incluso en los cuentos del ciclo del animal-novio, como señala Bettelheim (1977). El valor otorgado a la doncellez garantiza la legitimidad de la herencia en hijos propios (Rodríguez Almodóvar, 1994, p. 53). Consecuencia directa del amor y del matrimonio es la formación de una familia. En los cuentos clásicos la madre muchas veces aparece desaliñada y extenuada, en situaciones de estrés y lloro que los niños alivian con su afecto. Para Turin (1995), este estereotipo de la madre-sirvienta es el pilar del sexismo en la literatura infantil.

Todos estos aspectos son en general comunes a los cuentos populares españoles, aunque también hay diferencias significativas, según Rodríguez Almodóvar (1994). Los cuentos de costumbres, menos remotos en su origen y especialmente interesantes para el análisis del papel de la mujer en el imaginario 


\section{Marta Sanjuán Álvarez y María Ballarín Artigas}

colectivo de la sociedad española, presentan con frecuencia un argumento humorístico, y en ellos aparecen tanto príncipes como princesas forzados al matrimonio, pastores que aspiran a conseguir a la princesa, princesas tontas o caprichosas, doncellas casaderas recluidas hasta el matrimonio, mujeres a las que se les anula su personalidad, etc. A una etapa posterior pertenecen otros cuentos que revelan un matriarcado latente y, con él, una misoginia que da lugar a mujeres bravas, o débiles, falsas, de poco fiar. Otros, en fin, presentan mujeres astutas que resuelven los problemas, a veces burlándose del hombre que las quiere engañar. A pesar de esta diversidad de personajes femeninos, en general las mujeres ocupan un lugar secundario en los cuentos españoles.

¿Ha habido una revisión y evolución de estos estereotipos en la LIJ actual, para acomodarse a los nuevos roles sociales y culturales? Creemos que no todo lo que sería de esperar ni de la manera más satisfactoria. Desde mediados del siglo pasado encontramos niñas o mujeres protagonistas que superan ampliamente las características y capacidades anteriormente atribuidas a los personajes femeninos (Pastor, 2009). Algunas historias se basan en una simple inversión de roles y muestran personajes femeninos activos y transgresores frente a personajes masculinos débiles o bobos, como ocurre en algunas obras de N. Bosnia y A. Turin. Es también una tendencia consolidada en las últimas décadas la revisión de los cuentos tradicionales para adaptarlos a los nuevos valores. La reivindicación de personajes femeninos activos queda patente, por ejemplo, en numerosas versiones hipertextuales de Caperucita Roja, tales como ¡Te pillé Caperucita! (1994) de C. Cano, Cuentos infantiles políticamente correctos (1994) de J.F. Garner, Cuentos en verso para niños perversos (2008) de R. Dahl, o Una caperucita roja (2009), de Marjolaine Leray. En 1999 Teresa Colomer señalaba cómo a partir de los años 70 la LIJ parecía haber ido modernizando su representación del mundo en temas como la incorporación social y laboral de la mujer o la aparición de nuevas formas familiares. Sin embargo, una década más tarde (Colomer, 2010) advierte un estancamiento de esta evolución.

También las ilustraciones de los libros infantiles han suscitado el interés de los estudiosos en materia de literatura infantil y roles de género. Turin (1995) y Pastor (2009) encuentran numerosos símbolos sexistas: el delantal se asocia a la mujer; las gafas, símbolo de inteligencia, a los hombres, y si las llevan niñas o mujeres establecen una incompatibilidad entre belleza e inteligencia; los hombres leen periódicos, fuente de información y participación en la vida, mientras las mujeres leen novelas o cuentos, símbolo de evasión de la realidad. Otros símbolos recurrentes son la ventana o la sillita, que 


\section{La construcción de un pensamiento crítico acerca de los roles de género a través de la literatura infantil. ....}

Turin identifica con el encierro en la casa, la paciencia y la docilidad. Se asocia a la niña con el gato, ligado al hogar, pero también a las brujas y al diablo, mientras que al niño se le ve junto a un perro, animal 'de fuera', símbolo de lealtad, resistencia y coraje. Un estudio de Ros (2012/2013), que analiza la presencia de estereotipos en los cuentos ilustrados españoles actuales más difundidos en la provincia de Sevilla, desvela la vigencia de unos estereotipos similares a los descritos por Turin.

Otro fenómeno de claro tinte sexista ha sido la idea de que la LIJ debía proporcionar una oferta diferente para chicos y chicas. El subgénero 'novela para niñas', creado en los años 50 y 60, engloba aquellas obras con protagonistas femeninas que viven aventuras y peripecias, siempre con desenlace feliz y un claro contenido moralista (Díaz-Plaja, 2011). Todavía hoy se puede advertir la existencia de una LIJ específica para chicas, de la que son buen ejemplo las obras de Federico Moccia.

En definitiva, el estado de la cuestión aconseja promover en la escuela unas prácticas de lectura reflexiva que favorezcan la transformación social.

\section{Diseño de la investigación y de la intervención}

\subsection{Diseño de la investigación. Estrategias de recogida y análisis de datos}

La finalidad general de este trabajo es realizar y evaluar un diseño de intervención que fomente el pensamiento crítico en el alumnado de Educación Infantil y su reflexión en torno a la visión del género que la sociedad y la LI transmiten desde edades tempranas. Queremos dar la voz a los propios receptores infantiles, tener acceso a lo que piensan, para después analizar y categorizar sus respuestas lectoras, siguiendo la línea de investigación anglosajona (Arizpe y Styles, 2004; Sipe, 2000, 2002, 2010; Arizpe, 2013).

El diseño investigador sigue las fases descritas por Kemmis y McTaggart(1988) para la investigaciónacción: 1) clarificar y diagnosticar una situación problemática para la práctica; 2) formular estrategias de acción para resolver el problema; 3) poner en práctica y evaluar las estrategias de acción; 4) nueva aclaración y diagnosis de la situación problemática, y así sucesivamente. En nuestro caso, el problema que se quiere investigar se refiere a la función de la LI en la construcción de la identidad de niños y niñas de Educación Infantil. Más concretamente, se trata de investigar hasta qué punto la LI consigue transformar los esquemas cognitivos, éticos y socioculturales de los participantes en torno a los roles de género. El proceso investigador se ha desarrollado en dos fases, una previa a la intervención y otra 


\section{Marta Sanjuán Álvarez y María Ballarín Artigas}

durante la intervención, con distintos instrumentos de recogida y análisis de datos.

En la fase previa a la intervención se ha dirigido a los niños un cuestionario semiestructurado, a través de entrevistas orales individuales, con el objetivo de conocer sus ideas y creencias sobre el tema. Se combinan preguntas abiertas y cerradas en torno a la vida cotidiana de los niños (los juegos o las tareas domésticas) y a la literatura: cuentos preferidos, qué personajes les gustan más y cuáles menos, cómo deben ser y actuar los hombres y las mujeres en los cuentos, etc. En cuanto al tipo de preguntas, estas se encuadran en la tipología de preguntas posibles en la entrevista cualitativa, (Patton, 1984, cit. por Colás, 1994, p. 262): preguntamos sobre experiencias y comportamientos, sobre opiniones y valores, y sobre sentimientos y emociones.

\section{Tabla 2. Cuestionario previo a la intervención en el aula de $3^{\circ}$ de EI}

1. Me gusta jugar con chicos /chicas / chicos y chicas.

2. ¿Pueden hacer niñas y niños las mismas cosas (trabajar, jugar, estudiar...)? ¿Por qué?

3. ¿Me gusta jugar a fútbol? Sí/No.

4. ¿Pueden las chicas jugar a fútbol? ¿Por qué?

5. ¿Me gusta jugar a muñecas, princesas, mamás y bebés?

6. ¿Pueden los chicos jugar a muñecas, princesas, mamás y bebés? ¿Por qué?

7. ¿Está bien que los chicos lloren? ¿Por qué?

8. Me gusta jugar con chicos /chicas / chicos y chicas.

9. ¿Pueden hacer niñas y niños las mismas cosas (trabajar, jugar, estudiar)? ¿Por qué?

10. Las cosas de casa (cocinar y limpiar) son cosas de mamás / papás / mamás y papás.

11. Cuidar a los niños es cosa de mamás / papás / mamás y papás.

12. Cuidar a los ancianos (abuelos) cuando enferman es cosa de mamás / papás / mamás y papás.

13. ¿Me gusta leer cuentos y que me lean?

14. Mi cuento favorito es...

15. ¿Me gustan los cuentos de princesas? ¿Por qué?

16. Las princesas y las chicas de los cuentos tienen que ser... Valientes, guerreras y listas / Bellas, dulces y obedientes / Mandonas, gritonas y feas.

17. Los príncipes y los chicos de los cuentos tienen que ser...Valientes, guerreros y listos / Guapos, dulces y obedientes /Mandones, gritones y feos.

18. Cuando un príncipe y una princesa (un chico y una chica) quieren ser novios y casarse, ¿quién tiene que pedírselo a quién?: el chico / la chica / cualquiera.

19. ¿Son iguales los chicos en los cuentos y los chicos de mi clase? ¿Por qué?

20. ¿Son iguales las chicas en los cuentos y las chicas de mi clase? ¿Por qué?

21. ¿Qué personajes de los cuentos que conozco me gustan más? ¿Por qué?

22. ¿Qué personajes no me gustan? ¿Por qué?

23. ¿Me gustaría ser como algún personaje? ¿Como quién?

En lo que se refiere a la fase de intervención, el diseño ha tomado en consideración dos aspectos fundamentales:

1. La selección de un corpus de obras de LI adecuadas para los objetivos de investigación propuestos.

2. El desarrollo de siete sesiones de lectura y conversación literaria en el aula de los sujetos 
La construcción de un pensamiento crítico acerca de los roles de género a través de la literatura infantil. ....

participantes.

En esta fase las estrategias de recogida de información se encuadran dentro de un proceso de observación participante mediante la permanencia en el campo desde el doble rol de observadora y maestra. La observación participante constituye un método clásico de la investigación etnográfica que supone la recogida de la información directamente del escenario natural mediante la observación y participación en las actividades con los nativos (Kawulich, 2005). El análisis de los datos se ha centrado tanto en la evaluación del proceso como en los resultados de la intervención, es decir, en el análisis de la significatividad del corpus de obras seleccionadas y de las respuestas lectoras de los niños y niñas participantes en las conversaciones literarias, que han sido grabadas y transcritas con el fin de compararlas con sus ideas previas.

\subsection{Diseño de la intervención en el aula de $3^{\circ}$ de Educación Infantil}

Se han seleccionado siete obras de estilos y contextos temporales muy diversos, desde un cuento de Andersen y dos cuentos populares españoles a obras de literatura infantil contemporánea, lo que permite contemplar la cuestión con una perspectiva temporal y evolutiva. Todas ellas favorecen poner el foco de atención en los roles de género, bien a través de la caracterización de los personajes, bien porque adoptan un enfoque feminista explícito. El corpus seleccionado constituye un itinerario de lectura en torno a un eje temático. Estos itinerarios de lectura favorecen los procesos de comparación entre obras y, con ello, el desarrollo de habilidades de lectura más complejas, como señala Mendoza (2008).

Se ha tenido en cuenta, como indica Chambers (2007), que cada obra literaria elegida contiene unas potencialidades para la conversación. Puesto que la conversación literaria es el pilar básico del diseño de la intervención, la selección ha procurado la diversidad de los enfoques temáticos y literarios, con el objetivo de incitar la comparación y el debate, teniendo en cuenta la edad de los participantes. Las sesiones de lectura y conversación literaria tuvieron una duración aproximada de una hora cada una, y se desarrollaron a razón de una o dos por semana.

Presentamos el corpus de obras siguiendo el orden de las sesiones:

1) Ferrándiz, J. (1955). La ardilla hacendosa. Barcelona: Edigraf, 1985. 
Marta Sanjuán Álvarez y María Ballarín Artigas

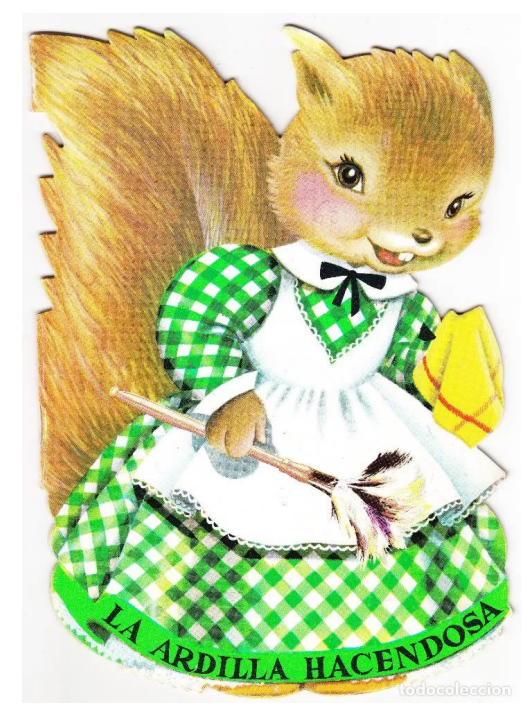

Figura 1. La ardilla hacendosa.

Cuento escrito e ilustrado por Ferrándiz y publicado a mediados de los años 50. Narra en un verso ágil la vida de una ardilla trabajadora y hogareña y la de su vecina, una coneja perezosa que no sabe cuidar de su hogar. Al final la ardilla ve recompensados sus esfuerzos y su bondad con la obtención del premio en un concurso en el que compite con la coneja. Tanto el texto como las ilustraciones representan de forma explícita los estereotipos sexistas y los ideales educativos de la Sección Femenina en lo que concierne a las niñas, como se advierte claramente en este pasaje referido a la protagonista: «Y nunca fue vanidosa, / no olvidando, como esposa, / de atender a su marido, / ante todo bien servido, / la ropa limpia y planchada, / la cena muy bien guisada. / En orden, sin un desliz, / en paz, era hogar feliz.» 2) Turin, A. (1976). Arturo y Clementina. Ilustr. de N. Bosnia. Pontevedra: Kalandraka, 2012.
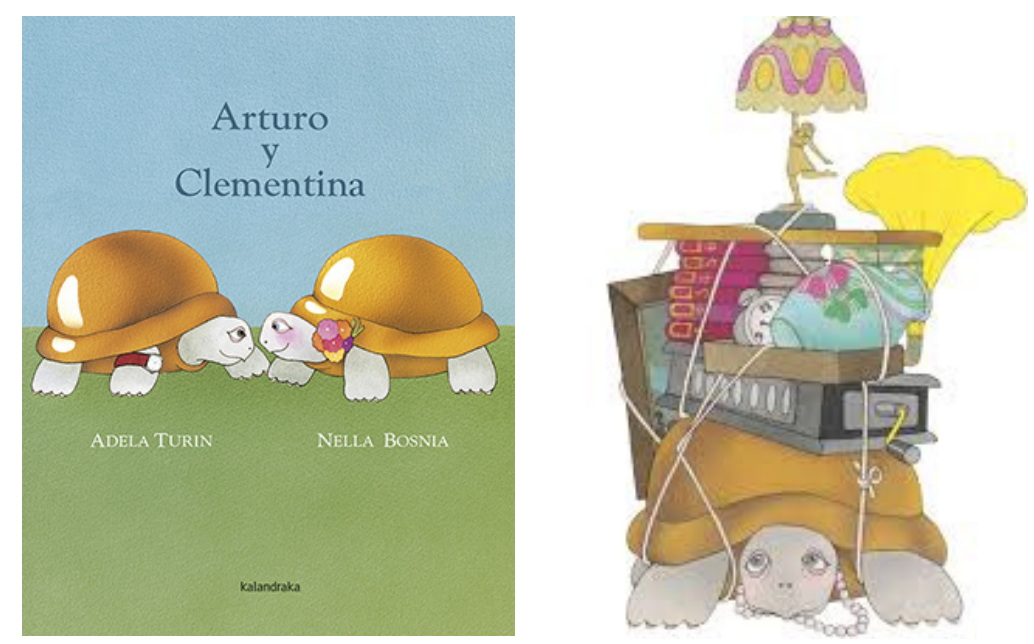

Figura 2. Arturo y Clementina 
La construcción de un pensamiento crítico acerca de los roles de género a través de la literatura infantil. ....

Esta obra se encuadra en una corriente de literatura infantil feminista en auge en la década de los 70 . Esta LI feminista tiene el mérito de haber denunciado unos esquemas culturales fuertemente arraigados. Sin embargo, en este caso la construcción literaria dirige hacia un mensaje excesivamente didáctico, lo que le resta valor literario. Las tortugas protagonistas (macho y hembra) están caracterizadas sin matices ni explicación de los motivos de su comportamiento.

3) "La hija del limosnero". En Rodríguez Almodóvar, A. (1983). Cuentos al amor de la lumbre. Volumen II (pp. 459-460). Madrid: Anaya.

4) “La mata de albahaca”. En Rodríguez Almodóvar, A. (1983). Cuentos al amor de la lumbre. Volumen II (pp. 435-438). Madrid: Anaya.

En estos dos cuentos populares españoles destaca el protagonismo de muchachas astutas que vencen las dificultades gracias al ingenio, en una línea frecuente en los cuentos populares españoles de costumbres, según Rodríguez Almodóvar (1994).

5) Andersen, H. C. (1835). La princesa del guisante. Ilustr. de D. Duntze. Barcelona: Lumen, 1984.
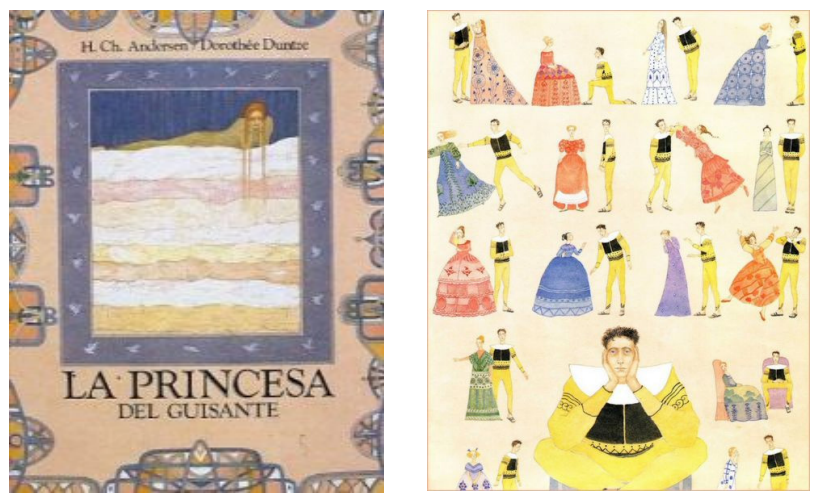

Figura 3. La princesa del guisante

Este conocidísimo cuento de Andersen presenta de manera implícita unos estereotipos tradicionales sobre el amor, la elección de pareja y las cualidades femeninas. Las ilustraciones de Dorothée Duntze refuerzan estos mensajes.

6) Bruel, C. (1976). Clara, la niña que tenía sombra de chico. Ilustr. de A. Bozellec. Barcelona: Lumen, 1980. 


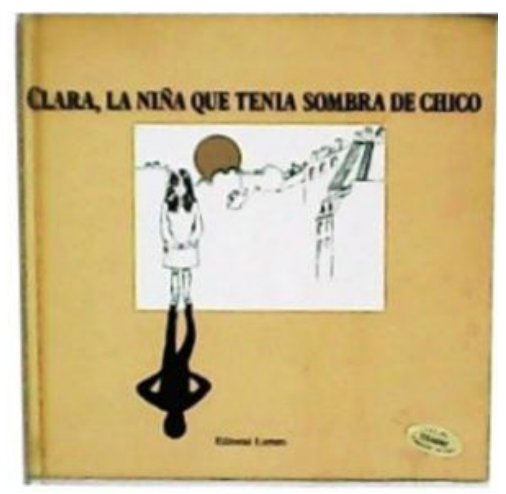

Figura 4. Clara, la niña que tenía sombra de chico

También esta obra se encuadra en la LI feminista de los 70. Muestra a los lectores infantiles un mensaje de aceptación personal frente a la asignación de etiquetas que dificultan el proceso de construcción de la identidad femenina o masculina en la infancia y adolescencia. La trama narrativa se desarrolla de manera abierta y sugerente tanto en el texto como en las ilustraciones, aunque al final el mensaje se presenta de manera excesivamente explícita.

7) Browne, A. (1989). El túnel. México: FCE, 1992.

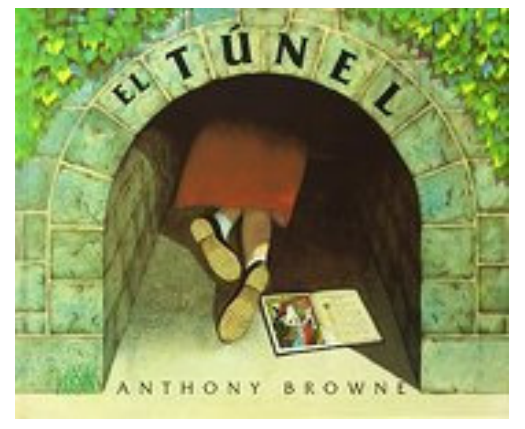

Figura 5. El túnel

A través del texto y de las imágenes, este libro álbum narra la superación de los roles iniciales adoptados por los dos hermanos protagonistas, chico y chica, en un proceso de emancipación paralelo.

El diálogo guiado con los lectores infantiles, siguiendo el enfoque Dime (Chambers, 2007), actúa como un andamiaje para el aprendizaje literario, cultural y social. Hablar sobre las obras leídas ayuda a los niños al crecimiento intelectual y emocional, ya que la discusión alimenta las habilidades cognitivas de alto nivel, ofrece experiencias, ayuda a aprender a tolerar situaciones y favorece la reflexión. 
La construcción de un pensamiento crítico acerca de los roles de género a través de la literatura infantil. ....

La conversación cooperativa incita a cada receptor a pensar en voz alta, liberar sus pensamientos, comunicar y compartir las ideas. Por otra parte, Sipe (2010) señala que la conversación literaria ocurre en dos terceras partes durante la lectura y solo un tercio después. Por ello, en las sesiones se ha dejado a los niños hablar e intervenir tanto antes de la lectura, para que formularan hipótesis previas, como durante y después de la lectura. Las sesiones han comenzado, en todos los casos, con la lectura en voz alta por parte de la mediadora.

La conversación se basa en los distintos tipos de preguntas que propone el enfoque Dime: básicas, generales y específicas. Con respecto a las preguntas básicas, se pregunta a los niños si les ha gustado la obra, qué es lo que más les ha gustado y qué es lo que menos. Después se introducen preguntas generales acerca del final, si la obra les recuerda a otras leídas anteriormente o qué pasajes les han gustado más. Se termina con preguntas sobre las ilustraciones y, sobre todo, acerca de los personajes, con el objetivo de enfocar la conversación en torno a la cuestión del género. Al hilo de lo que los niños comentan y argumentan en el momento de la conversación se plantean nuevas preguntas. La labor de la mediadora se ha centrado en animar la conversación y el análisis, dar participación a todos, ofrecer turnos de palabra y tiempos para expresarse.

\section{Análisis de resultados}

\subsection{Respuestas al cuestionario}

El análisis del cuestionario valora los datos obtenidos en cada pregunta, con un enfoque tanto cuantitativo como cualitativo. Se ha considerado oportuno, debido a la diferencia de respuestas entre niños y niñas, dividir el análisis según su sexo.

Con respecto a la pregunta 1, Me gusta jugar con chicos/chicas/ambos (Gráfico 1), resulta interesante que solo un $20 \%$ de los chicos y un $30 \%$ de las chicas responda que prefiere el juego con personas de su mismo sexo, pues se pudo observar en el contexto natural que niños y niñas tendían a jugar en grupos formados por personas de su mismo sexo. Parecen comprender que es más enriquecedor jugar con personas independientemente de su género, pero no lo demuestran en la realidad. 
Marta Sanjuán Álvarez y María Ballarín Artigas

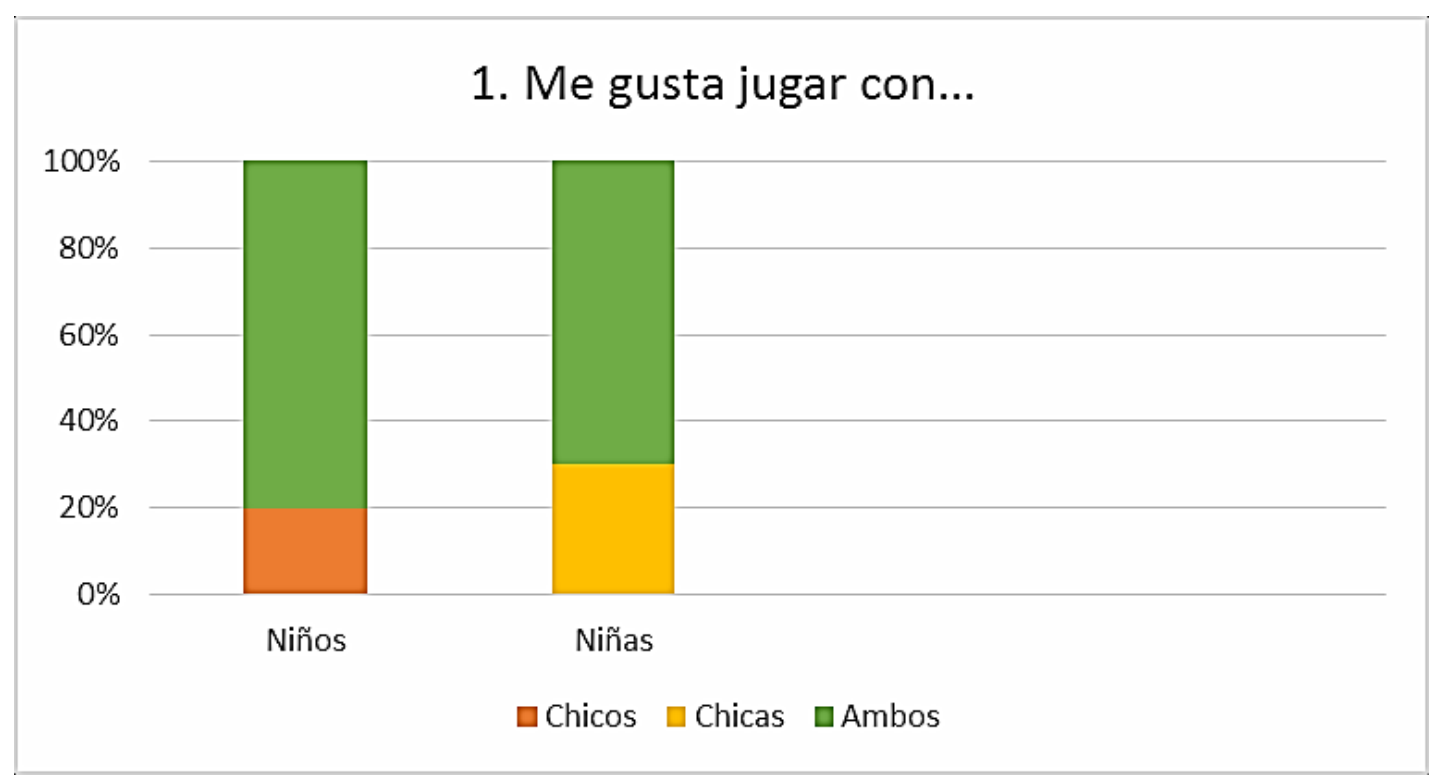

Gráfico 1

En cuanto a la pregunta 2, ¿Pueden hacer niños y niñas las mismas cosas? (Gráfico 2) resulta asombroso que el $80 \%$ de las niñas opine que niños y niñas no pueden hacer el mismo tipo de cosas, frente a solo un $20 \%$ de los niños. Son ellas más sexistas que los chicos. Los argumentos para las respuestas negativas aluden a que chicos y chicas son muy diferentes entre sí y por eso no pueden hacer lo mismo.

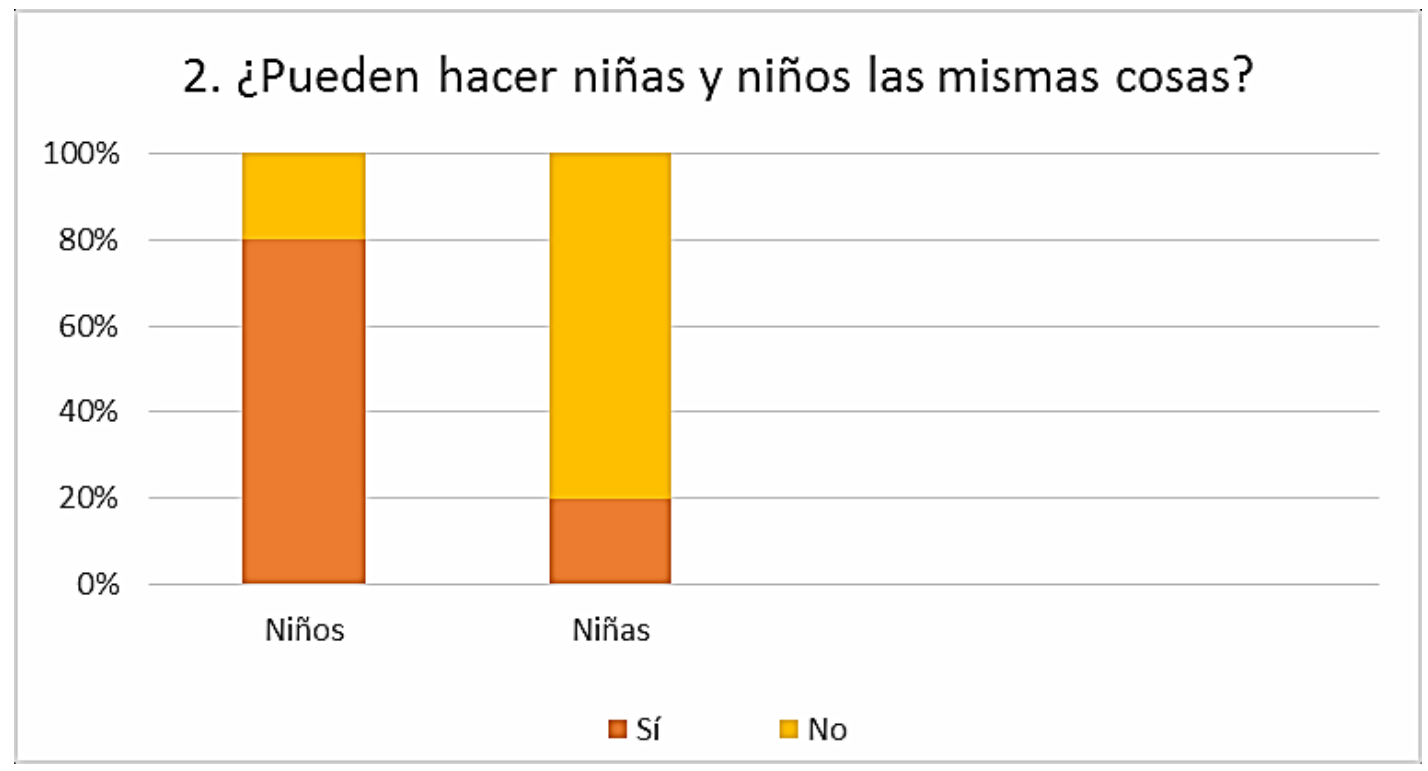

Gráfico 2 
La construcción de un pensamiento crítico acerca de los roles de género a través de la literatura infantil. ....

A la pregunta ¿Me gusta jugar al fútbol?, todos los chicos responden que sí, frente a un $30 \%$ de las chicas (Gráfico 3). A la pregunta ¿Pueden las chicas jugar a fútbol?, un $20 \%$ de las niñas y otro tanto de los niños piensan que las chicas no pueden, porque no les gusta, no saben o porque es un deporte masculino (Gráfico 4).

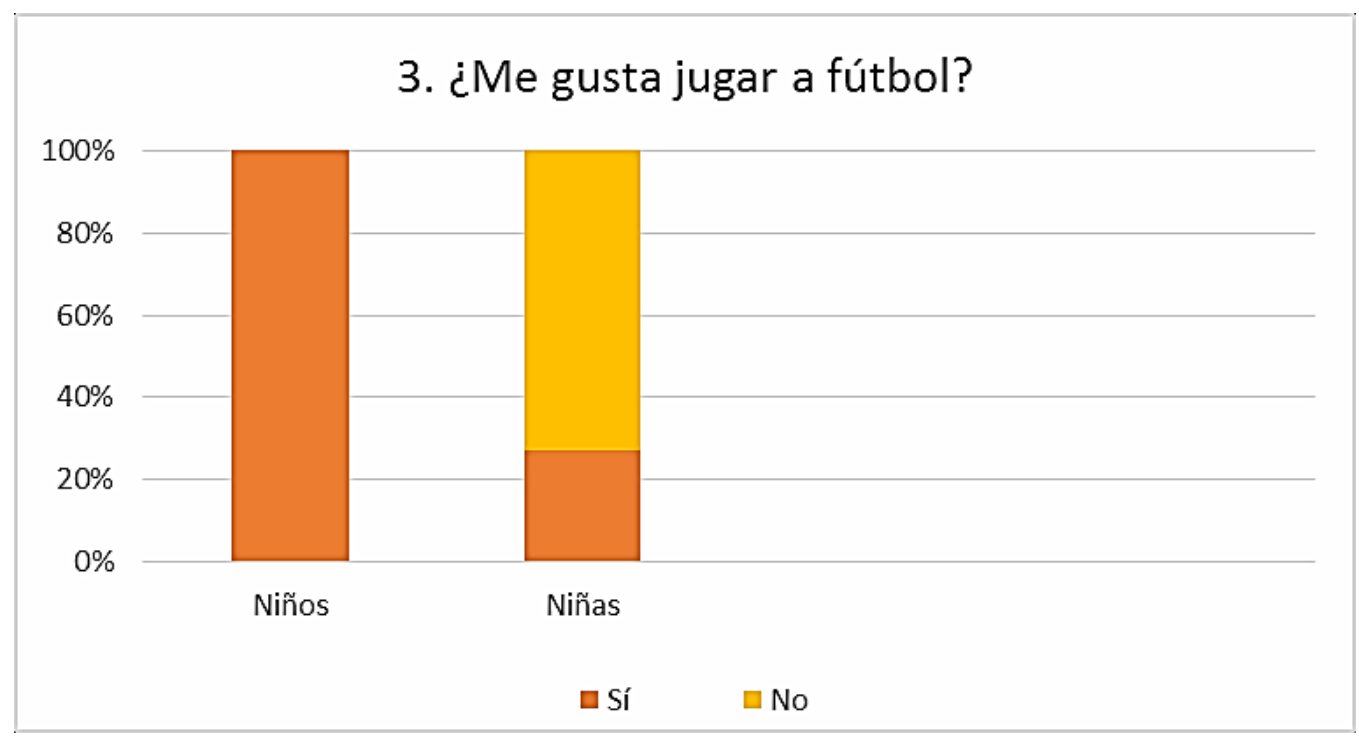

Gráfico 3

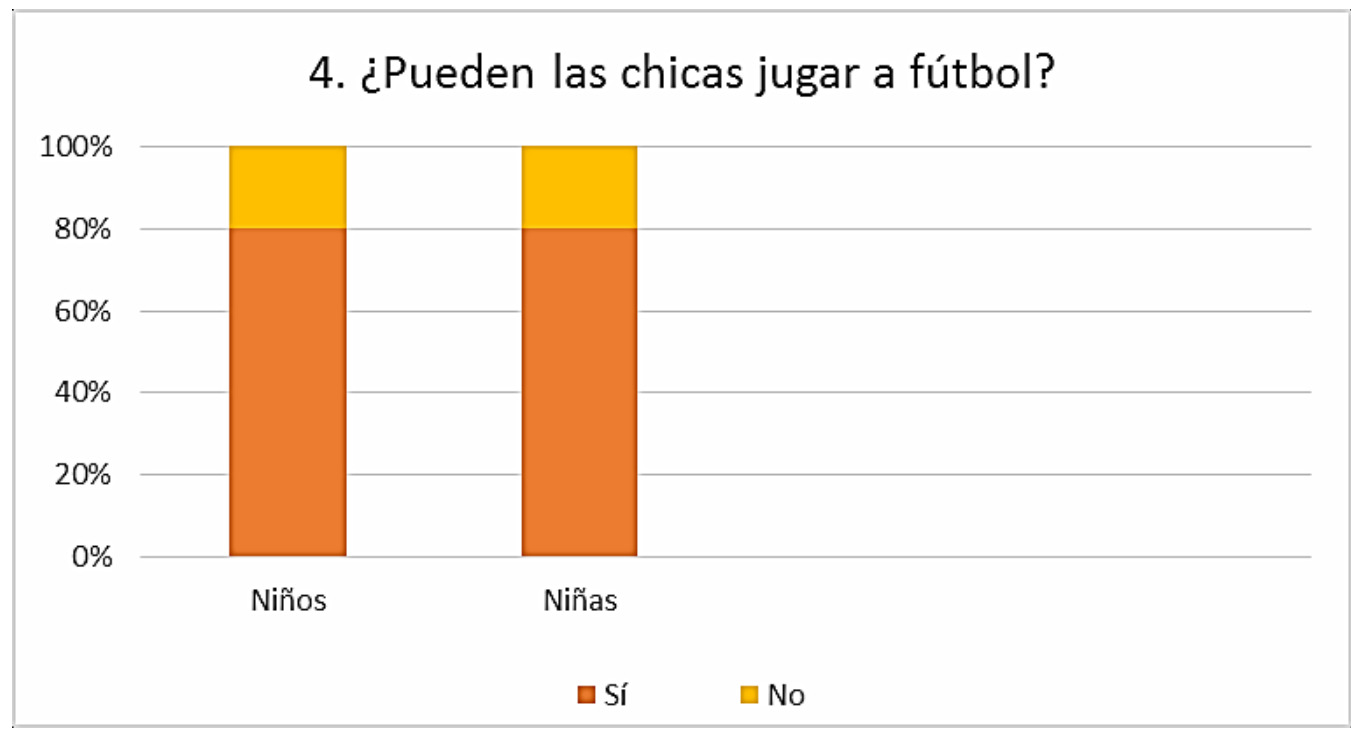

Gráfico 4

Con respecto a las preguntas ¿Me gusta jugar a muñecas, princesas, mamás y bebés? ¿Pueden los chicos jugar a muñecas, princesas...? (Gráficos 5 y 6) nuevamente no resulta llamativo que el 100\% de los niños responda que no les gustan esos juegos y el 100\% de las niñas afirme que les encantan. Sí parece reseñable que un $60 \%$ de los niños crea que está bien que los chicos jueguen a muñecas, a pesar de haber respondido que a ellos no les gustan, frente a solo un $40 \%$ de las niñas. 
Marta Sanjuán Álvarez y María Ballarín Artigas

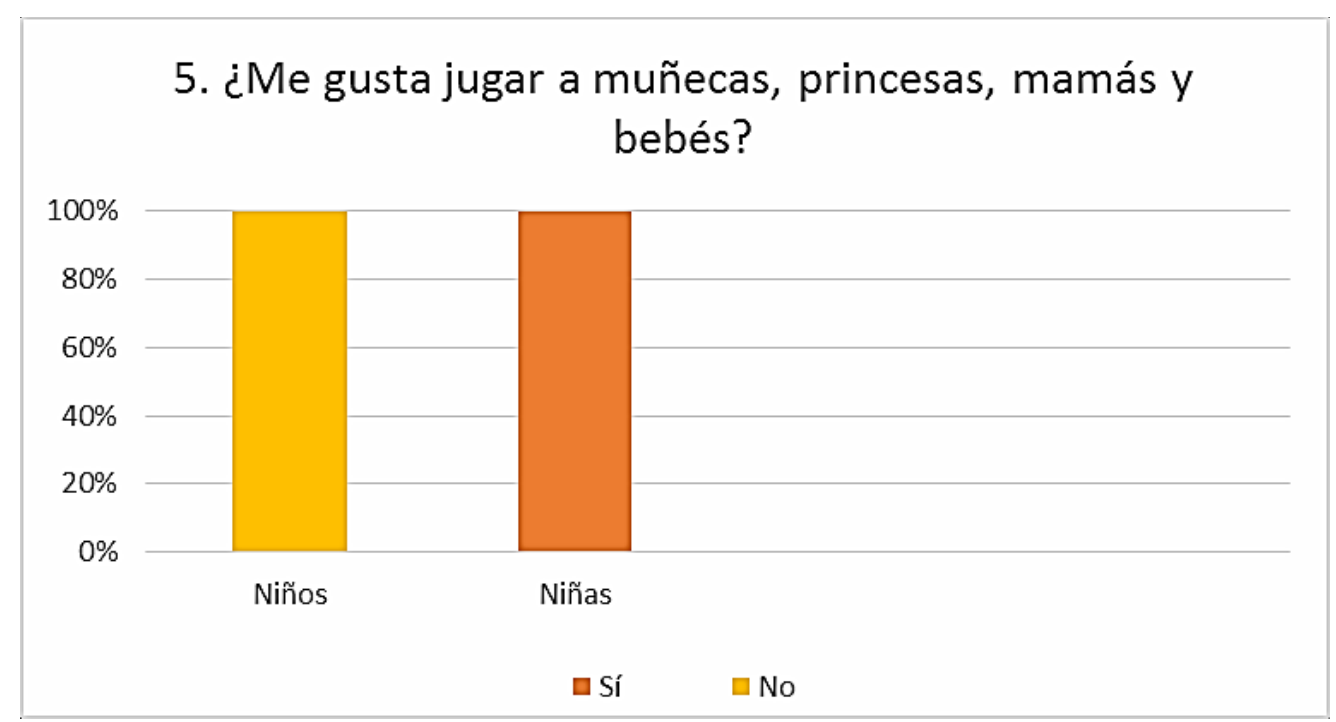

Gráfico 5

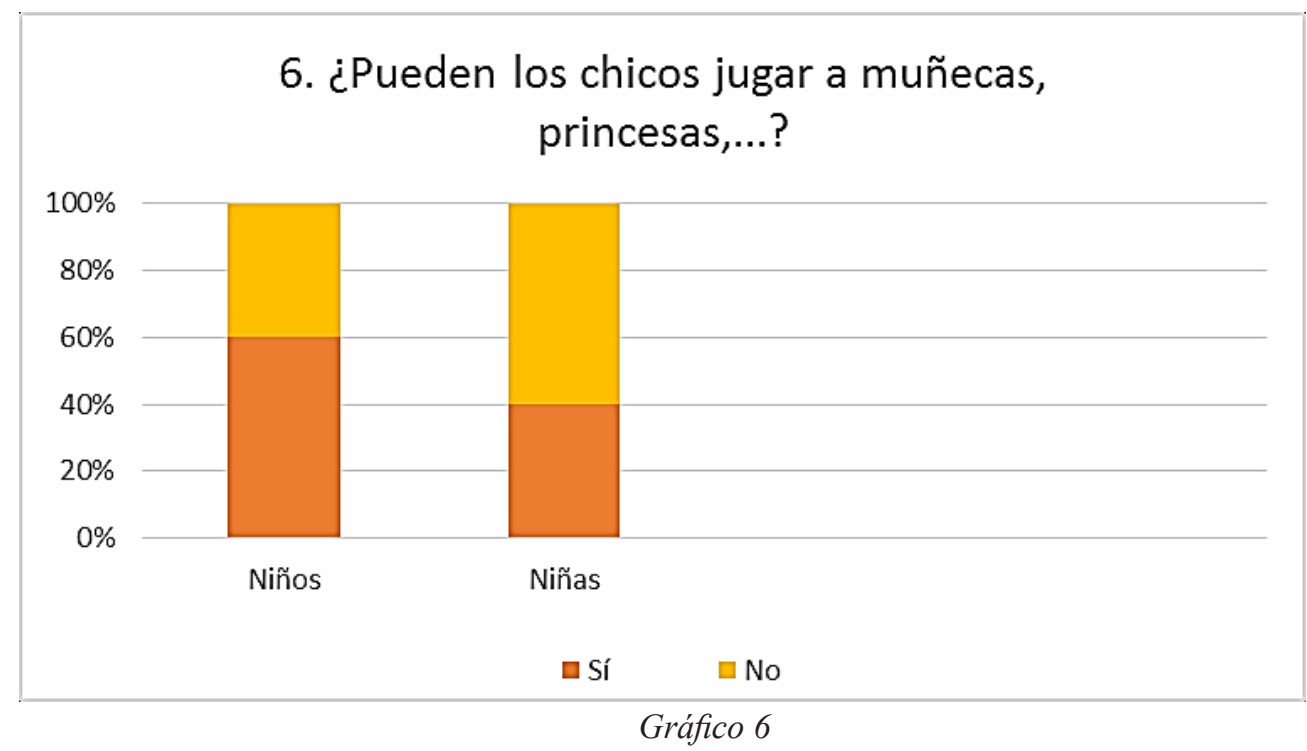

A la pregunta ¿Está bien que los chicos lloren? (Gráfico 7), un 30\% de las niñas considera que llorar no es apropiado para chicos, frente al 20\% de los niños. Alegan que llorar es de chicas y de "lloricas", y los chicos deben ser valientes. 
La construcción de un pensamiento crítico acerca de los roles de género a través de la literatura infantil. ....

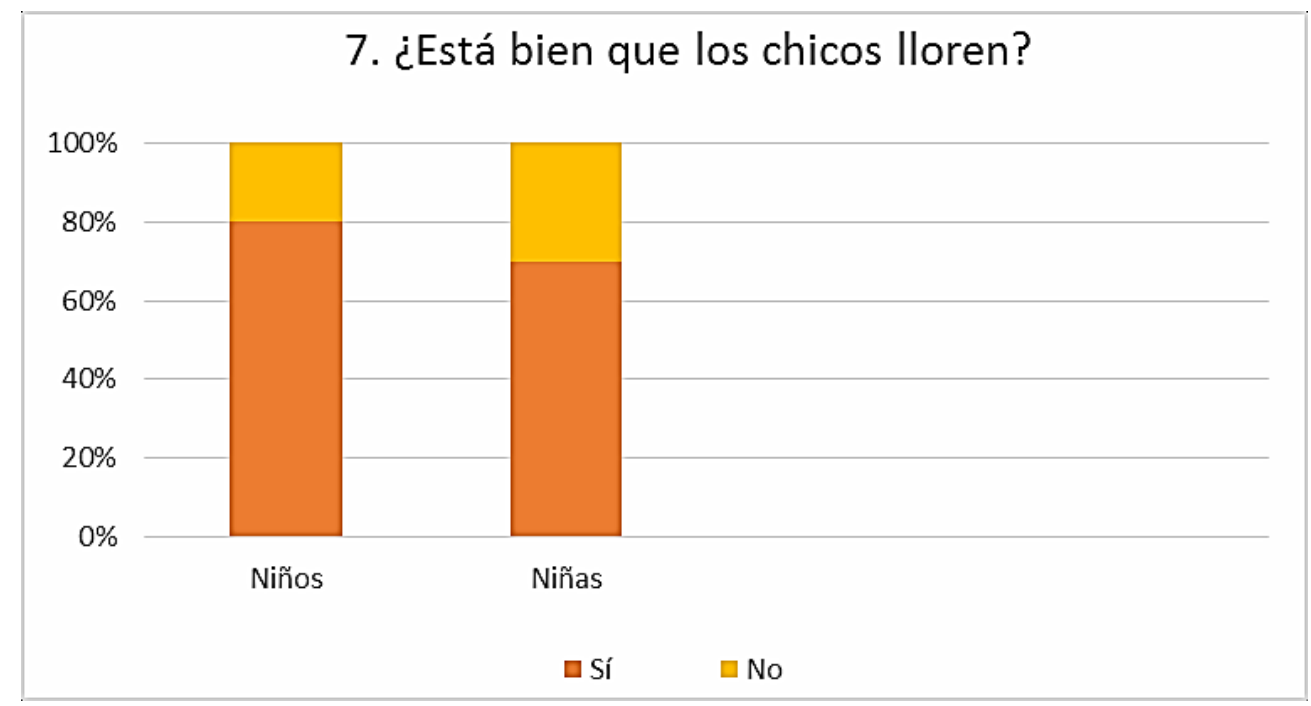

Gráfico 7

En las preguntas relacionadas con las labores de la casa y el cuidado de la familia, el grupo refleja ideas muy variadas (Gráficos 8, 9 y 10). El 100\% de las niñas está a favor del reparto entre padres y madres del cuidado de niños y ancianos, pero un 30\% piensa que las tareas de la casa son propias de las mamás. Sin embargo, todavía un 40\% de los niños considera que el cuidado del hogar y de los hijos corresponde exclusivamente a las mujeres. Las niñas defienden una igualdad en las tareas del hogar.

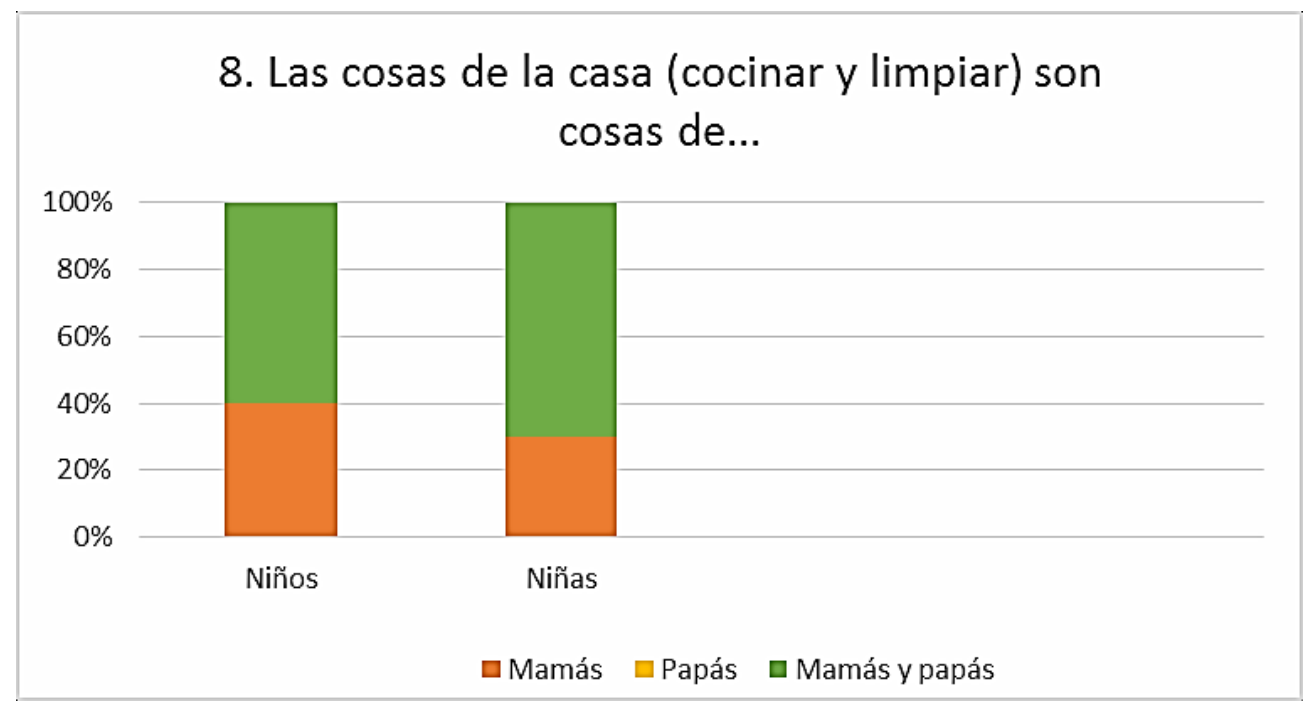

Gráfico 8 
Marta Sanjuán Álvarez y María Ballarín Artigas

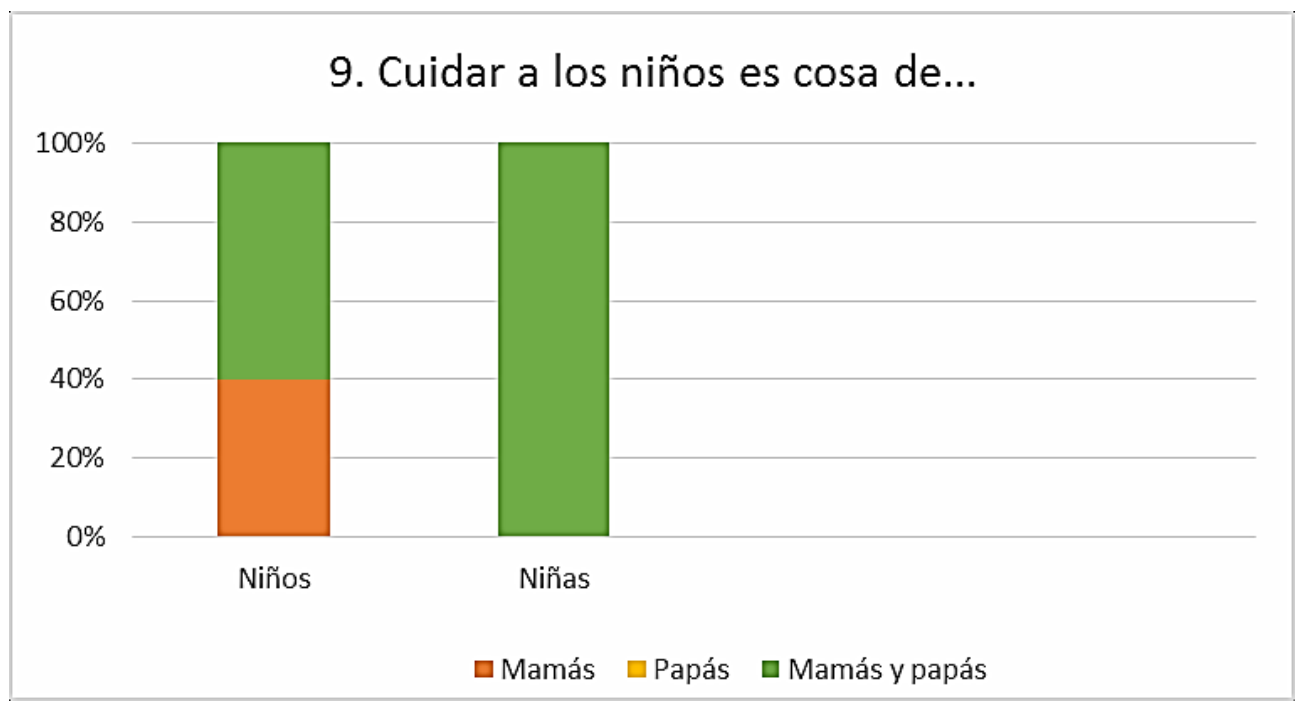

Gráfico 9

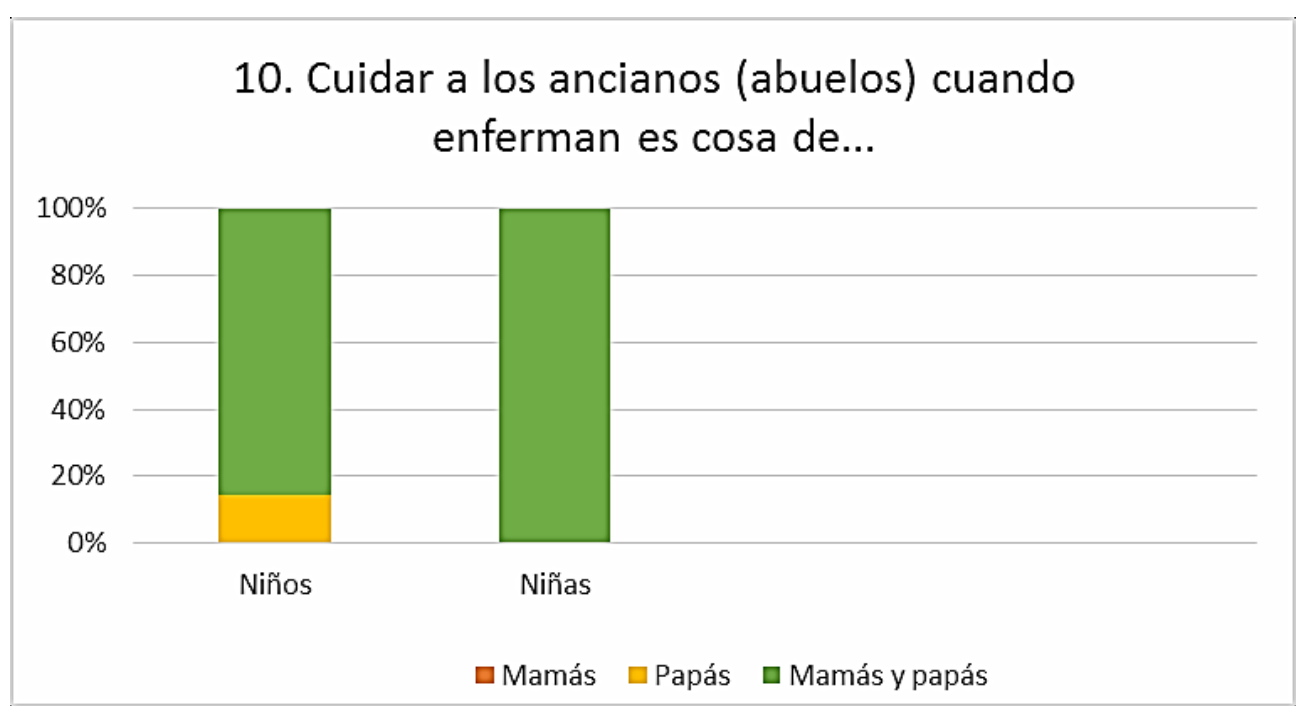

Gráfico 10

A la pregunta Me gusta leer cuentos y que me lean, todo el grupo responde de manera afirmativa. En cuanto a sus cuentos favoritos, los niños dan títulos como Las aventuras de Buzz Lightyear, San Jorge y el dragón, Te quiero Valero, Los tres cerditos o Rayo McQueen. Para las niñas sus obras favoritas son historias de princesas, bailarinas y hadas como Rapunzel, Princesas, La sirenita, Cenicienta, Frozen o Caperucita Roja. Los cuentos de princesas solo gustan al 10\% de los niños, frente al 100\% de las niñas. Los argumentos a favor se refieren a que son historias amor, con finales felices y bodas y, en el caso de algunas chicas, que son cuentos para niñas. Los niños a los que no les gustan estas historias 


\section{La construcción de un pensamiento crítico acerca de los roles de género a través de la literatura infantil. ....}

alegan que son cuentos para niñas.

En las preguntas 13 y 14 sobre cómo deben ser los personajes de los cuentos, expresan unas características estereotipadas en función del género del personaje. Los chicos y príncipes deben mostrarse valientes e inteligentes según el $80 \%$ de los niños y el $50 \%$ de las niñas, mientras que respecto a las chicas y princesas un $60 \%$ por igual de los niños y las niñas valoran la belleza, la amabilidad o la obediencia.

A la pregunta 15 , referida a quién pide en matrimonio, un $50 \%$ de los chicos y un $60 \%$ de las chicas responden que es el hombre quien lo debe hacer (Gráfico 11). Cuentos y películas muestran que la mujer debe esperar y comportarse de forma adecuada para que un hombre la corteje y quiera casarse con ella. Es reseñable que un $10 \%$ de las chicas responda que es la mujer quien debe pedir matrimonio a su marido. Los demás opinan que cualquiera de los dos puede hacerlo.

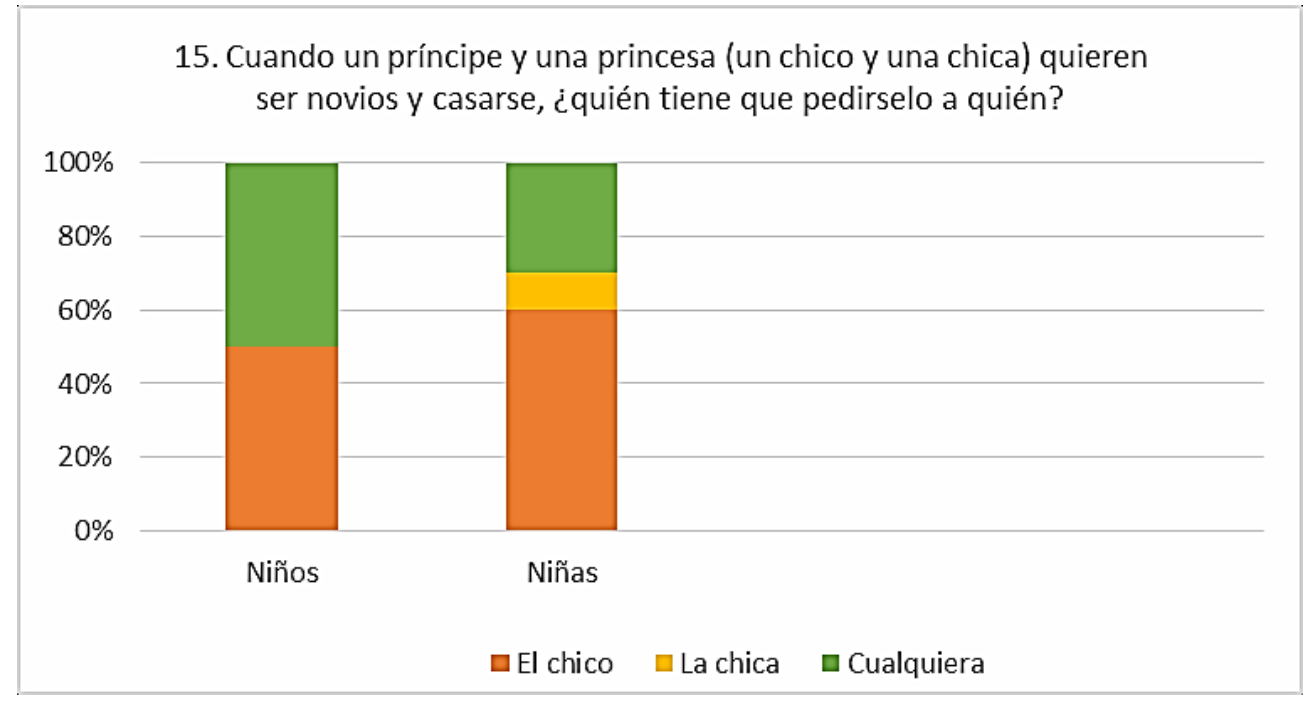

Gráfico 11

Con respecto a si son iguales los personajes masculinos y femeninos de los cuentos en comparación con los chicos y chicas de clase, una amplia mayoría contesta negativamente (Gráficos 12 y 13). Los argumentos aluden a que los chicos de clase no son caballeros, no llevan espada ni armadura, no son príncipes, no son valientes ni guerreros. Entre las chicas de clase y las de los cuentos las diferencias son de tipo físico: no tienen el pelo largo ni llevan vestido todos los días, y tampoco viven en castillos. No aluden a la forma de ser y actuar. 
Marta Sanjuán Álvarez y María Ballarín Artigas

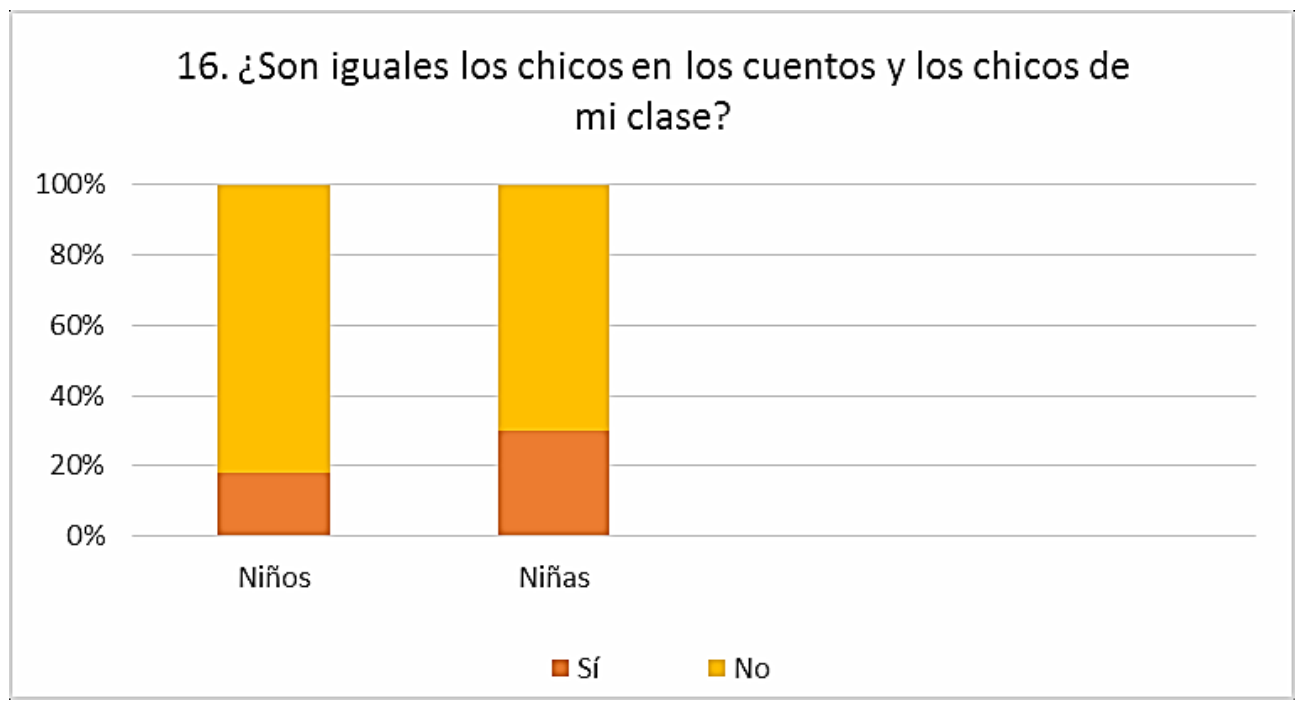

Gráficos 12

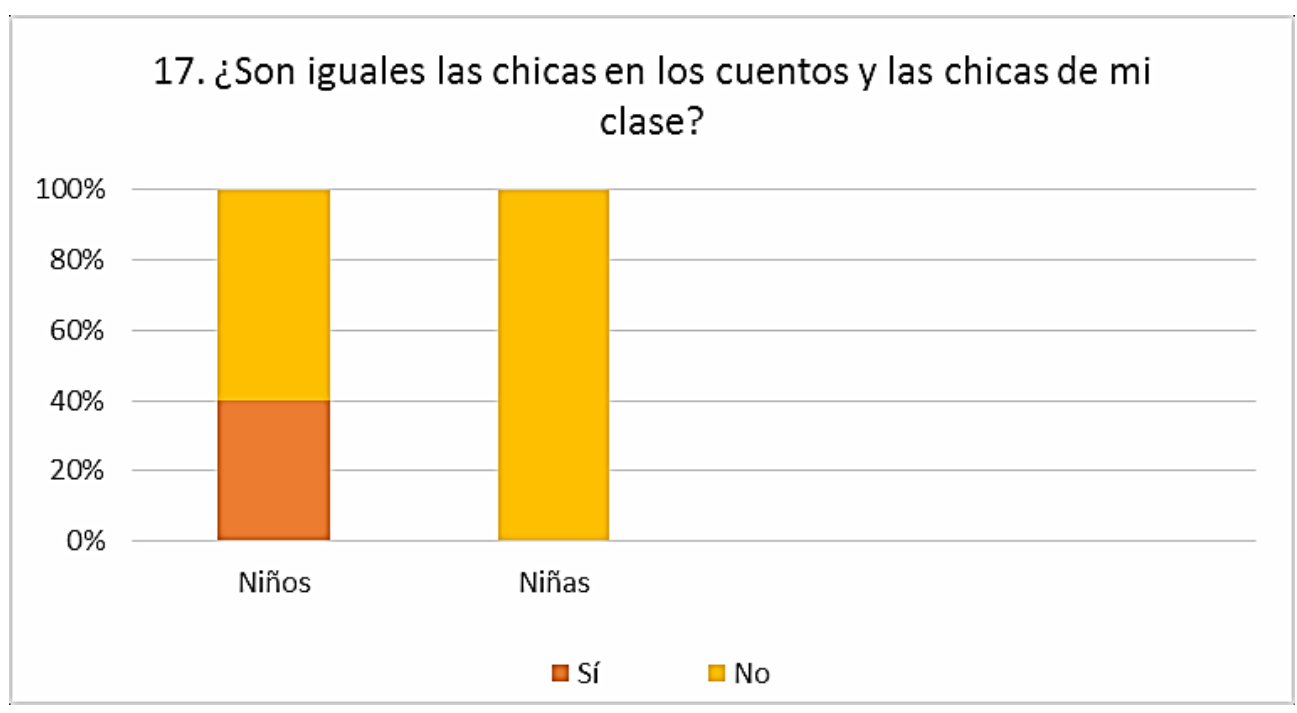

Gráfico 13

Como respuesta a la pregunta 18, ¿Qué personajes de los cuentos que conozco me gustan más? ¿Por $q u e ́ ?$, los niños nombran a Rayo McQueen, Pinocho, el mayor de Los tres cerditos y Buzz Lightyear, mientras que las chicas nombran a Mulán, la Bella Durmiente, Elsa, Ariel, Cenicienta y otras princesas. Niños y niñas tienden a elegir personajes de su mismo sexo que ostentan las características típicas de cada género.

En la pregunta 19, ¿Qué personajes no me gustan? ¿Por qué?, tanto los chicos como las chicas nombran a diversos personajes malvados, al Patito Feo y al Lobo Feroz. 
La construcción de un pensamiento crítico acerca de los roles de género a través de la literatura infantil. ....

A la pregunta 20, ¿Me gustaría ser como algún personaje?, los chicos señalan que les gustaría ser como el cerdito más listo de Los tres cerditos, como un gigante o un monstruo, mientras que las chicas desearían ser como diversas princesas (Mulán, Rapunzel, Elsa, Blancanieves...) debido a su belleza y a su precioso cabello.

En síntesis, el análisis nos permite observar que niños y niñas consideran que las personas pertenecientes a uno u otro género tienen unas características determinadas, previamente fijadas, que les condicionan a la hora de realizar tareas y actividades. Así, las niñas se ven como tranquilas, guapas y obedientes, prefieren juegos de muñecas, libros de princesas, se identifican con personajes femeninos delicados y bellos, y están más preparadas para la realización de tareas como el cuidado de los hijos y del hogar. Mientras, los chicos se consideran valientes, guerreros e inteligentes, prefieren una literatura bélica o de acción, así como juegos activos que implican movimiento, como el fútbol. Son personas dinámicas y decididas y, por ello, se dedican a tareas físicas y al trabajo fuera del hogar y son quienes deben decidir cómo y con quién casarse.

Estos resultados confirman el primer presupuesto inicial del estudio: los niños y niñas de Educación Infantil ya tienen unas ideas sexistas sobre los roles de género en la vida y en la literatura infantil. Sin pretender dar una explicación simplista de un fenómeno cultural tan complejo, es evidente que esas ideas se basan en sus experiencias vitales y en las imágenes que la sociedad pone a su alcance a través de los medios de transmisión cultural. Se trata ahora de verificar si la literatura infantil, a través de la recepción crítica guiada, puede contribuir a la reflexión y a la modificación de esos esquemas de pensamiento.

\subsection{Análisis de las respuestas lectoras a las conversaciones literarias}

\section{Sesión 1: La ardilla hacendosa}

A la vista de la cubierta comentan que el cuento va a ser sobre una ardilla hembra, atribuyendo el delantal y el plumero a la imagen femenina. Tras la lectura, los participantes se muestran contentos con el cuento y con su final, especialmente con que la ardilla gane una moto como premio a sus cualidades. Para ellos, la ardilla encarna el papel de protagonista bondadosa, que realiza las tareas domésticas y es limpia y ordenada. Califican a la coneja como perezosa, desordenada y sucia, y señalan que no es una buena ama de casa. Surge un debate acerca de las tareas domésticas y quién debe realizarlas. La 
Marta Sanjuán Álvarez y María Ballarín Artigas

mayoría defiende que las madres cocinan mejor y se encargan mejor del cuidado del hogar y de los niños, alegando que se les da mejor que a los hombres:

42. INVEST: ¿Las mamás saben cocinar bien? ¿Todas las mamás cocinan bien?

43. TODOS: Sí.

44. INVEST: ¿Y los papás?

45. TODOS: ¡No! No saben, el mío no...

46. INVEST: ¿Quién ha dicho que no saben cocinar? ¿No sabe cocinar su papá o todos los papás del mundo?

47. DAVID: Mi papá a veces hace la cena, y cocinan juntos.

48. SARA: Mi padre no sabe porque no practica.

49. INVEST: Y en los cuentos que conocéis ¿quién cocina, lava, cuida a los niños...?

50. DAVID: ¡Yo qué sé!

51. GABRIELLA: ¡Siempre son las chicas y las mamás!

52. BEATRIZ: Porque las mamás tienen que cuidar al bebé...

53. ISABEL: Y porque cocinan más mejor que los chicos.

Solo tres niñas y un niño defienden el reparto de tareas entre hombres y mujeres:

62. INVEST: Y la señora ardilla, que siempre estaba cocinando, limpiando... ¿Creéis que estaría contenta de hacer esas cosas?

63. FERNANDO: Igual se cansaba.

64. ISABEL: Debería ayudarle el marido.

65. CELIA: Sí porque hacerlo sola es aburrido.

66. DAVID: O igual es que el marido estaba trabajando.

67. INVEST: Igual es obligatorio que el papá trabaje y la mamá haga el trabajo de casa...

68. TODOS: Discuten entre ellos, unos dicen sí y otros que no.

69. ANA: No, porque si todos ensuciamos tenemos que ayudar a limpiar todos.

70. BEATRIZ: Sí, y los papás tienen que ayudar a las mamás.

71. ISABEL: En la casa tienen que limpiar todos.

72. DAVID: Sí, y ayudar a cuidar a los bebés.

Advierten que el marido de la coneja se queja del desorden, pero tampoco él se ocupa de las tareas domésticas:

89. DAVID: Pues a mí no me ha gustado nada de nada cuando el papá conejo no trabajaba y aun encima solo se quejaba. Lo quería todo limpio, pero no limpiaba.

90. ANA: A mí lo mismo, porque si no te gusta lo puedes hacer tú mismo.

Tras un breve debate concluyen que hombres y mujeres deben contribuir a las labores de cuidado del hogar en el que viven, a pesar de que inicialmente identificaban la cocina o la limpieza como tareas de la mujer. Se ha producido un cambio en sus esquemas éticos y un avance hacia la igualdad entre géneros.

\section{Sesión 2: Arturo y Clementina}

Tras la lectura, los niños se muestran contentos con la historia y se animan a participar más que 


\section{La construcción de un pensamiento crítico acerca de los roles de género a través de la literatura infantil. ....}

en la anterior sesión. Resaltan que les ha gustado que Clementina fuese cada vez más feliz con su vida gracias a los paseos que podía dar, en lugar de permanecer sola en casa todo el día. Sin embargo, no están de acuerdo con que abandone su hogar. Se plantea entonces un debate entre la felicidad y lo que uno debe hacer. Algunos señalan que Clementina tiene derecho a ser feliz y está bien que se marche para conseguir su objetivo, mientras que otros están en desacuerdo:

16. INVEST: ¿Qué no os ha gustado?

17. FERNANDO: Pues cuando se iba de casa porque no le compraba Arturo lo que ella quería.

18. ISABEL: No, era cuando le decía que todo el rato decía tonterías.

19. GABRIELLA: Sí, a mí eso no me ha gustado nada.

20. ALEJANDRA: A mí no me ha gustado nada de nada que Clementina cada vez tenía más cosas en la concha.

21. INVEST: ¿Por qué?

22. ALEJANDRA: Porque no era feliz, aunque tenía muchas cosas...

23. DAVID: Sí, pero Clementina se iba del mundo... De su casa, que diga.

24. INVEST: ¿Por qué no te ha gustado eso?

25. DAVID: Porque dejaba solo a Arturo y él siempre le regalaba cosas y le llevaba la comida.

26. ANA: Pero es que Arturo también la dejaba sola en casa todo el día y aun así se enfadaba todo el rato y le decía que decía tonterías.

$[\ldots]$

30. ALEJANDRO: A mí tampoco me ha parecido bien...

31. GABRIELLA: Pues porque deja solo a Arturo y es su marido...

32. DAVID: A mí me gusta y no me gusta. Me gusta porque así Clementina se lo pasaría bien, pero no me gusta porque deja solo a su marido.

33. PAOLA: Pero es que Clementina se ha cansado de que la deje muchas veces sola ya y se va.

34. ANA: Claro.

35. DAVID: Sí pero ahora Arturo también se ha quedado solo.

36. BEATRIZ: Pero ha empezado él dejando a la tortuga sola y aburrida en casa...

Establecen un patrón común con La ardilla hacendosa puesto que en ambas obras el marido no contribuye a las tareas del hogar. Se debate si Arturo es buena persona o no. Algunos dicen que solo quiere lo mejor para Clementina, por eso le hace regalos y le lleva comida. Otros, por el contrario, creen que Arturo solo piensa en sí mismo, humilla a Clementina y no se esfuerza por hacerla feliz. Se puede observar el dilema de los alumnos entre lo que la sociedad considera que está bien y lo que nos hace felices. Los niños, a su nivel, han planteado un debate ético en torno a lo que se puede y lo que se debe hacer, sin llegar a ninguna idea clara. Sí parecen concluir que es necesario que Arturo intente hacer feliz a su mujer, para lo cual debe escucharla y permitirle hacer aquellas actividades que a ella le gustan en lugar de colmarla de regalos innecesarios.

Sesión 3: La hija del limosnero

No a todos les gusta este cuento. Muchos se quejan de la violencia de hechos como cortarle los 


\section{Marta Sanjuán Álvarez y María Ballarín Artigas}

dedos a uno de los personajes. Otros, en cambio, justifican estas acciones debido a que con ellas la protagonista busca salvar su vida. Establecen patrones de conexión entre los personajes principales, la niña y el padre, y Arturo y Clementina. En ambas historias la mujer, indefensa y delicada, permanece en el hogar realizando las tareas domésticas mientras el hombre sale a trabajar y a buscar comida. Han planteado estas similitudes entre uno y otro cuento porque han empezado a cuestionar esos estereotipos, y especialmente el hecho de que sea la mujer quien permanece en el hogar.

26. BEATRIZ: [El padre] era bueno porque quería a su hija y le llevaba pan y limosna a casa.

27. ALEJANDRA: ¡Anda! Le llevaba comida a casa como las tortugas... como Arturo a Clementina.

28. FERNANDO: ¡Ahí va! Pues es verdad...

29. SARA: Sí, porque los chicos le llevan la comida a las chicas y las mamás.

30. INVEST: ¿Ah sí?

31. VÍCTOR: A veces sí y a veces no.

32. PAOLA: Sí, cuando la mamá no se puede mover porque cuida los bebés le lleva la comida el papá...

33. INVEST: Pero la hija del limosnero no estaba cuidando a ningún bebé. Ella estaba en casa...

34. YESSICA: Pero era pequeña para ir a por el pan y su papá la dejaba en casa.

Así pues, son capaces de reflexionar acerca de los roles de género en relación con los trabajos y tareas que unos y otros pueden desempeñar, tanto en la vida real como en la literatura. Por otra parte, debaten sobre la valentía e inteligencia de la niña y admiten que niños y niñas pueden ser igualmente valientes, debate que también se suscita en otras sesiones. La inteligencia y la valentía son características generalmente asignadas al género masculino. Podemos observar cómo este estereotipo forma parte del imaginario del grupo, que comenta con asombro la valentía y astucia de la joven protagonista:

16. INVEST: Bueno y... ¿qué os ha gustado?

17. GABRIELLA: Cuando la niña se escapaba.

18. SARA: Cuando la niña era muy valiente y descubría al malo las dos veces.

19. EDUARDO: ¿Dos veces?

20. SARA: Sí, cuando lo veía en casa por el agujero de la cerradura de la llave y cuando la quiere tirar al pozo antes de tirarlo a él.

21. ALEJANDRO: A mí me había gustado cuando se encerraba en el cuarto y el malvado no podía entrar.

\section{Sesión 4: La princesa del guisante}

Tras observar la cubierta y leer el título, algunos niños reconocen el cuento. La conversación gira en torno a si las princesas y las chicas son delicadas y sensibles, o si han de serlo. Hay disparidad de opiniones entre los que creen que la delicadeza es una característica intrínseca al sexo femenino y los que aseguran que las chicas son diferentes unas de otras. Algunas niñas parecen rebelarse y afirman 


\section{La construcción de un pensamiento crítico acerca de los roles de género a través de la literatura infantil. ....}

que ni ellas ni todas las mujeres son delicadas. No ocurre lo mismo en el caso de los chicos, que mantienen la idea de que las niñas, y sobre todo las princesas, se caracterizan por su delicadeza:

81. FERNANDO: Porque solo una princesa era tan sensible para notarlo mientras dormía debajo de 20 colchones.

82. VÍCTOR: Porque las chicas son muy delicadas...

83. INVEST: ¿Todas las princesas y las chicas son delicadas?

84. SARA: Yo no soy delicada...

85. DAVID: Pero las princesas sí...

86. ANA: No todas.

87. BEATRIZ: Yo creo que algunas sí que lo notarían y otras no, depende de cada una porque no todos somos iguales.

Las niñas también defienden que las mujeres pueden ser valientes y luchadoras, tema recurrente a lo largo de las sesiones, mientras que los chicos las tildan de cobardes. Las niñas han intentado convencerles de que no todas las mujeres son dulces, delicadas o cobardes. Han establecido, para ello, patrones con otros cuentos y películas infantiles que ofrecen ejemplos de heroínas valientes, como Mulán o Mérida:

56. FERNANDO: Y, ¿por qué las princesas siempre tienen miedo?

57. ANA: ¿Cómo van a tener miedo de un guisante?

58. TODOS: Risas.

59. FERNANDO: No, de un guisante no...

60. ALEJANDRO: Sí, tienen miedo por si les atacan... y a veces son un poco miedicas.

61. VÍCTOR: Es verdad que son unas miedicas.

62. ALEJANDRA: Algunas sí, pero hay muchas que no.

63. ISABEL: Algunas princesas son valientes. $[\ldots]$

68. INVEST: ¿Cuáles no tienen miedo?

69. ANA: Mérida...

70. CELIA: Mulán no tiene miedo.

Por otra parte, debaten acerca del amor y el matrimonio analizando los cuentos que conocen y comparando con lo que ocurre en la vida real. La mayoría asegura que a la hora de casarse el chico busca a la chica, por lo que se muestran muy contentos cuando es el príncipe quien recorre el mundo entero en busca de su princesa.

20. ALEJANDRA: Pero el príncipe sí que estaba buscando a una princesa.

21. ISABEL: Es que lo tienen que buscar los chicos.

22. INVEST: Que levante la mano quien crea que son los chicos quienes tienen que buscar a la princesa.

23. Levantan la mano 15.

24. INVEST: Y ahora, ¿quién no ha levantado la mano?

25. AINARA: Yo.

26. INVEST: ¿Y eso? ¿Es que crees que tienen que buscar las chicas al príncipe? 


\section{Marta Sanjuán Álvarez y María Ballarín Artigas}

27. ISABEL: ¿¡Qué dices!? Que mi papá buscó a mi mamá para casarse.

28. ANA: Pues mis padres se encontraron y se conocieron, y como se gustaban y se querían se casaron porque creían que el otro era guapo.

29. ALEJANDRO: Pues vaya asco. ¡Yo no me quiero casar con una chica!

30. DAVID: Pues yo creo que a veces la chica busca al chico y otras veces es el chico...

31. VÍCTOR: Pero en los cuentos es el chico que encuentra a la chica y ya se casan.

Siguiendo con esta línea, debaten si un matrimonio puede ser feliz cuando dos personas se casan sin conocerse. La mayoría considera una locura que dos personas se casen sin saber apenas el nombre del que será su marido o su esposa. Sin embargo, en el caso de los cuentos no ven inconveniente en que se puedan casar sin apenas conocerse. Comparan esta historia con otros cuentos y películas infantiles en las que las princesas contraen matrimonio tras ver al príncipe:

32. ALEJANDRA: Sí, y a veces casi ni se conocen.

33. ANA: La princesa del guisante no conocía al príncipe, pero lo quería y se casaban.

34. DAVID: Pues igual no lo quería tanto... porque si no se sabía ni su nombre...

35. AINARA: ¡Yo no me voy a casar nunca!

36. BEATRIZ: ¡Claro! Es que ni se conocían aun encima.

37. DAVID: Ni Cenicienta conocía al príncipe.

38. ISABEL: ¡Sí! Sí lo conocía.

39. INVEST: Sí, lo conocía de que había bailado un poquito con él, ¿verdad?

40. JULIÁN: Y la princesa del guisante ni le había visto la cara al príncipe del guisante.

41. ALEJANDRA: Pero sí que se querían.

42. SARA: Sí, porque se querían mucho aunque no se conocían...

43. FERNANDO: María, ¿podemos querer mucho a alguien, aunque no lo conozcamos? ¿Tanto para casarnos...?

44. INVEST: Yo no lo sé... pero yo creo que no.

45. DAVID: Solo para ser amigos a distancia.

46. YESSICA: Pero pueden ser felices si se casan...

47. SARA: ¡Pero cómo van a ser felices si ni saben sus nombres!

El grupo parece tener claro que en cuestiones de amor o matrimonio la vida real es muy diferente de la literatura o el cine.

\section{Sesión 5: La mata de albahaca}

El grupo se muestra muy satisfecho con la historia y resalta lo mucho que les gusta que la chica gaste bromas y haga trampas al príncipe. El debate se centra de nuevo en las características que asignan los cuentos a los personajes femeninos y masculinos:

14. INVEST: ¿Qué os ha parecido esta chica?

15. SARA: Muy guapa y lista.

16. ANA: Jo, pues era una niña muy valiente.

17. JULIÁN: Era muy lista.

18. BEATRIZ: A mí me ha gustado que fuera tan inteligente.

19. DAVID: Es que algunas princesas no son listas... 
La construcción de un pensamiento crítico acerca de los roles de género a través de la literatura infantil. ....

20. SARA: ¡Pero esta sí!

21. VÍCTOR: Y le ponía muchas trampitas al príncipe para reírse de él.

22. ALEJANDRO: ¡Y le daba con un mazo!

23. ISABEL: Pues hay otras princesas que son listas y valientes.

24. DAVID: La princesa del cuento de San Jorge no, porque le daba miedo un dragoncito.

25. BEATRIZ: Porque era un dragón muy grande que se la quería comer.

26. ISABEL: Pues la princesa de Brave es muy valiente...

De nuevo, tanto los niños como las niñas alaban la astucia y la valentía como cualidades de la chica, una característica propia de algunos cuentos populares españoles, pero menos frecuente en los cuentos que conocen.

Sesión 6: Clara, la niña que tenía sombra de chico

Este cuento no deja a nadie indiferente. El debate se centra en las diferencias entre chicos y chicas según lo que la sociedad les atribuye como características propias. El grupo asegura que las chicas tienden a ser más tranquilas y a portarse bien, y que les gusta cuidar su aspecto físico y estar guapas, mientras que los chicos son más activos y desobedientes. En este caso, son los niños quienes defienden que ellos no siempre se portan mal ni son brutos o torpes, en un intento de romper con los estereotipos atribuidos a su género. Todos opinan en contra de los prejuicios existentes para uno y otro género, y llegan a un nivel de reflexión mayor que en otras ocasiones:

2. VÍCTOR: No he entendido bien por qué le crecía a Clara la sombra de chico.

3. DAVID: Porque era como un chicazo.

4. BEATRIZ: Y sus padres lo llamaban chico todo el rato.

5. SARA: Sí, es que se portaba como un chico...

6. INVEST: ¿Cómo se portan los chicos?

7. BEATRIZ: Mal.

8. INVEST: ¿Sí?

9. TODOS: Se oye sí de chicas y algunos chicos, y se oye también no.

10. OMAR: Yo me porto un poco mal...

11. BEATRIZ: Casi todos los chicos se portan mal.

12. INVEST: ¿Y las chicas?

13. TODOS: ¡Bien! ¡Mal!

14. ALEJANDRO: Pues a veces bien y a veces mal... es según qué chicos y qué chicas, porque no porque seamos chicos nos vamos a portar siempre mal y las chicas siempre bien... $[\ldots]$

26. INVEST: Y, ¿qué me podéis decir de las cosas que hace Clara en esta imagen, y las cosas que hace su sombra de chico?

27. JULIÁN: Están jugando a fútbol.

28. DAVID: Y Clara juega con una muñeca y el chico la está destrozando.

29. YESSICA: Porque los chicos son unos brutos.

30. ALEJANDRA: Y lo rompen todo.

31. TODOS: Gritos y voces.

32. ANA: Algunos son brutos.

33. FERNANDO: Solo algunos... también algunas chicas son brutas.

34. YESSICA: Pues no. 
Marta Sanjuán Álvarez y María Ballarín Artigas

35. SARA: No, porque son chicas.

36. ALEJANDRO: Y son menos fuertes que los chicos.

37. BEATRIZ: Pues hay algunas chicas que son más fuertes que tú.

38. FERNANDO: Pero también hay algunas chicas que son un poco fuertes y que hacen bromas como los chicos...

Por el contrario, las niñas no toman la belleza y la obligación de mantenerse guapas como un prejuicio o estereotipo hacia su género que deban combatir o eliminar, aunque en el debate se flexibiliza el estereotipo:

17. EDUARDO: Y también le decían a Clara que se peinaba fatal...

18. FERNANDO: $\mathrm{Y}$ a veces las chicas se peinan mal...

19. ALEJANDRA: ¡No! Siempre se peinan bien.

20. SARA: Sí, para estar guapas.

21. DAVID: Y los chicos también se ponen gomina para ponerse guapos.

22. SARA: Sí, yo peino a mi hermano.

23. ALEJANDRA: Pero las chicas siempre son guapas.

24. FERNANDO: Y también puedes ser una chica y ser fea...

25. ALEJANDRA: Bueno, a veces...

Por primera vez las ilustraciones del cuento llaman realmente su atención. Comentan las diferencias entre las imágenes de la niña y su sombra. En algunos casos tanto niños como niñas intentan persuadir a sus compañeros de que no hay cualidades, acciones o juegos propios de uno u otro sexo. El debate termina con una defensa de la igualdad:

89. ANA: A mí todos los juguetes me parecen iguales. Me parece que los chicos y las chicas pueden hacer todo de lo mismo, si pueden todos vestirse, leer, comer o estar en el cole mezclados, pues también pueden las chicas jugar con garajes y coches y los chicos con las muñecas.

\section{Sesión 7: El túnel}

A la vista de la cubierta comentan que podía tratarse de una historia de terror o de misterio, ya que se ven unos pies que asoman por un oscuro túnel. Una vez leído, establecen comparaciones con otros cuentos como Caperucita Roja, sobre todo por el análisis de las imágenes. También comparan con la película Frozen, en la que la coprotagonista se convierte en hielo y después es salvada por el amor de su hermana.

En general, les gusta la historia y destacan como un hecho interesante que la niña se enfrente a sus temores para salvar a su hermano. Reaparece el tema de si las chicas son o no valientes, y esta vez la conclusión general del grupo es que todos, chicos y chicas, tenemos miedo en ocasiones, pero todos podemos ser valientes: 
La construcción de un pensamiento crítico acerca de los roles de género a través de la literatura infantil. ....

15. DAVID: Porque las chicas son un poco miedicas.

16. Se oyen gritos de negación por parte de las chicas y risas de los chicos.

17. FERNANDO: No tienen fuerzas...

18. ALEJANDRA: No son miedicas, y si pierden a un hermano y lo quieren mucho pues se atreven a todo por él.

19. AINARA: Pero no somos miedicas. $[\ldots]$

26. SARA: Todos podemos ser valientes.

27. ANA: Y todos tenemos miedo a veces... yo tengo miedo a las arañas...

En esta última sesión se puede observar el cambio que se ha producido en los esquemas previos del grupo. Una vez más surge el tema acerca de las aficiones o las actividades a las que pueden dedicarse según el género. En esta ocasión el grupo concluye que no es una cuestión de género, sino de cada persona concreta:

32. INVEST: ¿Son las chicas más tranquilas que los chicos?

33. ANA: Pues a veces a los chicos les gustan juegos más brutos como el fútbol...

34. SARA: Es que a veces aunque las chicas sean tranquilas también a veces son más brutas, y los chicos aunque no sean tan tranquilos a veces hay algunos que no son tan brutos... porque no siempre somos iguales.

\section{Conclusiones}

El estudio ha partido de dos presupuestos iniciales:

1) Los niños y niñas de Educación Infantil ya tienen unas ideas sexistas sobre los roles de género.

2) La literatura infantil, a través de la recepción crítica guiada, puede contribuir a la reflexión y a la modificación de los esquemas de pensamiento sobre los roles de género ya en la Educación Infantil.

El primer presupuesto se ha confirmado totalmente. Estos niños y niñas de EI ya tienen una idea estereotipada del género basada en sus experiencias personales y en las imágenes que la sociedad pone a su alcance a través de los medios de transmisión cultural. Del mismo modo, se identifican con personajes literarios de su género que perpetúan los estereotipos marcados durante siglos por una sociedad patriarcal que les va inculcando no solo qué tareas o aficiones son propias de uno u otro género, sino también qué cualidades y actitudes.

El segundo presupuesto también se confirma: la conversación literaria y el análisis guiado de las obras seleccionadas han llevado a los participantes a cuestionar los estereotipos iniciales y transformar sus esquemas éticos y socioculturales. A lo largo de la intervención los niños y las niñas han reaccionado 


\section{Marta Sanjuán Álvarez y María Ballarín Artigas}

a la ideología presente en los textos. Sus prejuicios respecto a las capacidades y aficiones de hombres y mujeres han disminuido o casi desaparecido en favor de una visión más igualitaria. Han sabido apreciar que los modelos caducos que ofrece cierta literatura infantil no son deseables para la vida real. En este proceso, las imágenes de los libros álbum o libros ilustrados han desempeñado un papel esencial.

Esta transformación de las creencias iniciales confirma el valor de la LI en la construcción de la identidad individual y en la percepción crítica de la realidad social, desde la primera infancia: $«[\ldots]$ la literatura constituye una de las herramientas culturales fundamentales para desarrollar una conciencia más lúcida del mundo y de la realidad humana» (Sanjuán, 2013, p. 147). Aunque literatura y ética deban mantener ciertas distancias por temor a subordinar la literatura a la moral, es evidente que los receptores infantiles hacen una lectura ética de las obras. En el tema que nos ocupa, no ha sido necesaria una literatura plagada de valores feministas. El corpus seleccionado ha dado buenos resultados porque enfoca el tema desde distintas posiciones ideológicas y tratamientos literarios de los personajes masculinos y femeninos, correspondientes a un lapso temporal muy amplio, lo que ha promovido la comparación y la reflexión. Consideramos especialmente relevante la polisemia de la obra literaria, es decir, el evitar didactismos explícitos que impiden la construcción de sentidos propios por los lectores infantiles.

Muchas de las respuestas obtenidas en las distintas conversaciones literarias confirman la idea de que los niños son capaces de lecturas críticas y pueden establecer conexiones entre distintas obras literarias, así como entre las obras literarias y su vida personal. En el análisis de las respuestas lectoras podemos advertir el predominio de las que Sipe (2010) categoriza como analíticas (los niños utilizan la información obtenida del texto y las ilustraciones para llevar a cabo la interpretación), intertextuales (establecen conexiones con otras obras conocidas) y personales (establecen conexiones entre las obras y sus experiencias personales). En las respuestas analíticas están utilizando principalmente los procesos cognitivos de la interpretación, mientras que en las respuestas intertextuales y personales hay un componente emocional importante. Los niños, como cualquier lector literario, interpretan los textos acudiendo a su intertexto vital, es decir, al conjunto de experiencias vitales, experiencias previas como lector, gustos estéticos, aficiones, hábitos de consumo cultural $\mathrm{y}$, sobre todo, unas maneras de leer impresionistas, de no experto (Sanjuán, 2013, p. 487). Los niños y niñas participantes no estaban acostumbrados a la conversación literaria, pero pronto han sido capaces de debatir con gran interés 


\section{La construcción de un pensamiento crítico acerca de los roles de género a través de la literatura infantil. ....}

aquellos aspectos de las obras literarias que podían relacionar con sus experiencias vitales.

Por otra parte, Eco (1979) sostiene que los textos llevan premisas ideológicas más o menos explícitas, ante las cuales el lector se sitúa. La intervención muestra cómo los receptores infantiles pueden asumir esas premisas, ignorarlas consciente o inconscientemente, o cuestionarlas. A lo largo de las sesiones, la literatura ha promovido reflexiones progresivamente más profundas sobre los textos y sobre el mundo que rodea a los receptores infantiles, todo ello gracias a una reflexión grupal y consensuada en la que se reflejan actitudes de flexibilidad mental y predisposición al cambio de los esquemas personales. La conversación literaria se erige en estrategia central de una educación literaria que se plantee estimular una recepción lectora crítica. Para ello, es decisivo seleccionar obras atractivas y saber realizar preguntas abiertas que den posibilidades de participación, así como decidir cuándo es el momento oportuno para ciertas preguntas y cuándo es necesario rehacerlas.

Una conclusión final se desprende del estudio realizado: la escuela debe desempeñar un papel esencial en la educación no sexista. La conversación en torno al papel de hombres y mujeres en las obras literarias, extensible a otras formas de representación cultural, nos indica un camino metodológico relevante para contribuir a la educación igualitaria.

\section{Referencias bibliográficas}

Aguilar, C. (2008). Lectura, género, feminismo y LIJ. Lenguaje y Textos, 28,113-128.

Argüelles, J. D. (2003). ¿Qué leen los que no leen? México: Paidós.

Argüelles, J. D. (2005). Historias de lecturas y de lectores. México: Paidós.

Arizpe, E. (2013). Imágenes que invitan a pensar: el 'libro álbum sin palabras' y la respuesta lectora. Reflexiones Marginales, 18. URL: http://reflexionesmarginales.com/3.0/22-imagenes-queinvitan-0. Última consulta:_10-7-2018.

Arizpe, E. y Styles, M. (2004). Lectura de imágenes. Los niños interpretan textos visuales. México: FCE.

Bajour, C. y Carranza, M. (2005). Abrir el juego en la literatura infantil y juvenil. Imaginaria, 158. URL: https://www.imaginaria.com.ar/15/8/abrir-el-juego.htm. Última consulta: 12-6-2018. Bettelheim, B. (1977). Psicoanálisis de los cuentos de hadas. Barcelona: Crítica. Cañellas, A. (1979). Los roles sexuales en la literatura infantil. Cuadernos de Pedagogía, 63, 19-22. 
Marta Sanjuán Álvarez y María Ballarín Artigas

Carranza, M. (2006). La literatura al servicio de los valores, o cómo conjurar el peligro de la literatura. Imaginaria, 181. URL: http://www.imaginaria.com.ar/18/1/literatura-y-valores.htm Última consulta:13-8- 2018.

Carranza, M. (2009). ¿Por qué la literatura es también para los niños? Imaginaria, 261. URL: http:// www.imaginaria.com.ar/2009/12/\%C2\%BFpor-que-la-literatura-es-tambien-para-los-ninos/ Última consulta:20-9-2018.

Carreras, A., Subirats, M. y Tomé, A. (2012). La construcción de las identidades de género en la etapa 0-3. Primeras exploraciones. En García Marín, J. \& Gómez Vázquez, M. B. Diálogos en la cultura de la paridad: reflexiones sobre feminismo, socialización y poder (pp. 35-55). Universidad de Santiago de Compostela.

Cashdan, S. (2000). La bruja debe morir. Madrid: Debate.

Cerdá, H. (1978). Literatura infantil y clases sociales. Madrid: Akal.

Cervera, J. (1984). La literatura infantil en la educación básica. Madrid: Cincel-Kapelusz.

Chambers, A. (2007). Dime: los niños, la lectura y la conversación. México: FCE.

Colás, P. (1994). La metodología cualitativa. En Colás, P. \& Buendía, L. Investigación educativa (pp. 249-290). Sevilla: Alfar.

Colomer, T. (1999). Introducción a la literatura infantil y juvenil. Madrid: Síntesis.

Colomer, T. (2010). Introducción a la literatura infantil y juvenil actual. Madrid: Síntesis.

Compagnon, A. (2007. Trad. 2008). ¿Para qué sirve la literatura? Barcelona: Acantilado.

Díaz-Plaja, A. (2011). Escrito y leído en femenino: novelas para niñas. Cuenca: UCLM.

Eco, U. (1979. Trad. 1981). Lector in fabula. Barcelona: Lumen.

Elliot, J. (1993). El cambio educativo desde la investigación-acción. Madrid: Morata.

Etxaniz, X. (2011). La transmisión de valores en la literatura, desde la tradición oral hasta la LIJ actual. Ocnos, 7, 73-84.

Kawulich, B.B. (2005). La observación participante como método de recolección de datos. FQS, 6 (2, art. 43). URL: http://www.qualitative-research.net/index.php/fqs/article/view/466/999 Última consulta: 21-11-2018.

Kemmis, S. y McTaggart, R. (1988). Cómo planificar la investigación-acción. Barcelona: Laertes. Larrosa, J. (2003). La experiencia de la lectura. México: FCE 
La construcción de un pensamiento crítico acerca de los roles de género a través de la literatura infantil. ....

Lewis, C. S. (1961. Trad. 2000). La experiencia de leer. Barcelona: Alba Editorial.

Machado, A.M. (2000). Ideología y libros para niños. Educación y biblioteca, 112, 24-33.

Machado, A.M. (2015). Censura, arbitrio y sus circunstancias. Ocnos, 14, 7-17. URL: https://revista. uclm.es/index.php/ocnos/article/view/ocnos_2015.14.01 Última consulta: 17-9-2018.

Mata, J. (2009). Lectura como experiencia ética. En Yubero, S., Caride, J. A. y Larrañaga, E. (coords.). Sociedad educadora, sociedad lectora (pp. 41- 61). Cuenca: UCLM.

Mata, J. (2014). Ética, literatura infantil y formación literaria. Impossibilia, 8, 104-121. URL: http:// ojs.impossibilia.org/index.php/impossibilia/article/view/102 Última consulta: 4-9-2018.

Molina, M.M. (2007). Lengua, literatura y género. Lenguaje y Textos, 26, 93-102.

Mendoza, A. (2008). Leer y comparar. Lenguaje y Textos, 28, pp. 19-41.

Pastor, A.A. (2009/10). Roles y diferenciación de género en la literatura infantil. Revista Borradores, X/XI, pp.1-11. URL: http://www.unrc.edu.ar/publicar/borradores/Borradores.htm

Peroni, M. (1998. Trad. 2003). Historias de lectura. México: FCE.

Petit, M. (1999). Nuevos acercamientos a los jóvenes y la lectura. México: FCE.

Petit, M. (2001). Lecturas: del espacio íntimo al espacio público. México: FCE.

Rico, L. (1986). Castillos de arena. Ensayo sobre literatura infantil. Madrid: Alhambra.

Rodríguez Almodóvar, A. (1994). El texto infinito. Madrid: FGSR.'

Ros García, E. (2012/13). El cuento infantil como herramienta socializadora de género. Cuestiones Pedagógicas, 22, 329-350. URL: http://institucional.us.es/revistas/cuestiones/22/art_15.pdf Última consulta: 6-11-2018.

Rosenblatt, L. (1938/1995. Trad. 2002). La literatura como exploración. México: FCE.

Salinas, P. (1948. Reed. 2002). El defensor. Madrid: Alianza.

Sánchez Corral, L. (1995). Literatura infantil y lenguaje literario. Barcelona: Paidós.

Sanjuán, M. (2007). El discurso literario en la construcción del sujeto: la escritura autobiográfica como fuente de información. Lenguaje y Textos, 26, 63-78.

Sanjuán, M. (2013). La dimensión emocional en la educación literaria. Zaragoza: Prensas Universitarias de Zaragoza.

Sanjuán, M. (2018). La ideología en la literatura infantil. Evaluación de un proceso de enseñanzaaprendizaje en la formación inicial de maestros. En Tabernero, R. (ed.). Arte y oficio de leer 
Marta Sanjuán Álvarez y María Ballarín Artigas

obras infantiles. Investigaciones sobre lectores, mediación y discurso literario (pp. 157-164). Barcelona: Octaedro.

Sanjuán, M. y Senís, J. (2017). Literatura e identidad. Experiencias de lectura literaria en la infancia y adolescencia de cinco escritores españoles contemporáneos. Álabe, 15, 1-19. URL: http:// revistaalabe.com/index/alabe/article/view/357/256 Última consulta: 29-9-2018.

Sipe, L. (2000). The construction of literary understanding by first and second graders in oral response to picture storybook read-alouds. The Reading Teacher, 35(2), 252-275.

Sipe, L. (2002). Talking back and taking over: Young children's expressive engagement during storybook read-alouds. The Reading Teacher, 55(5), 476-483.

Sipe, L. (2010). Cómo responden los niños a los álbumes ilustrados: cinco tipos de comprensión lectora. Conferencia impartida el 5/2/2010 en el Máster "Libros y literatura para niños y jóvenes" UAB. URL: http://literatura.gretel.cat/sites/default/files/conferencia_sipe_0.pdf. Última consulta:15-10-2018.

Tejerina, I. y Echevarría, E. (2007). Formación del lector y educación en valores: estética y ética de la literatura. En Cerrillo, P.; Cañamares, C. y Sánchez, C. (coords.). Literatura infantil: nuevas lecturas, nuevos lectores (pp. 269-278). Cuenca: UCLM.

Turin, A. (1995). Los cuentos siguen contando: algunas reflexiones sobre los estereotipos. Madrid: Horas. 